\title{
Survival of financially distressed SMEs and out-of-court versus in-court reorganization: explanatory internal factors
}

\author{
Montserrat Manzaneque $^{\mathrm{a}}$, Elena Merino ${ }^{b}$, Jesús Antonio Sánchez ${ }^{\mathrm{c}}$ \\ a) Facultad de Ciencias Sociales, University of Castilla-La Mancha. Cuenca, Spain. \\ b) Facultad de Derecho y Ciencias Sociales, University of Castilla-La Mancha. Ciudad Real, Spain. \\ c) Facultad de Ciencias Jurídicas y Sociales, University of Castilla-La Mancha. Toledo, Spain.
}

\footnotetext{
${ }^{b}$ Corresponding author.

E-mail address: elena.merino@uclm.es
}

\section{A R T I C L E I N F O}

Article history:

Received 20 November 2018

Accepted 11 November 2019

Available online 1 January 2021

\section{JEL classification:}

C13

G01

G33

G34
K22

M40

\section{Keywords:}

Keywor
SMEs

liquidation

failure

reorganization

out-of-court reorganization

in-court reorganization

\section{A B S T R A C T}

The Directive (EU) 2019/1023 of $20^{\text {th }}$ June 2019 on preventive restructuring frameworks, have highlighted the need to evaluate, the possibilities of restructuring insolvent companies, but viable in the future. Based on the Theory of Resources, this research aims to identify those internal factors that contribute to explain the differences in the outcome of failure SMEs. To do this, a sample of 6,285 Spanish SMEs that failed in the 2008-2010 period was used and the evolution of each of them during the 2011-2013 period is observed. We have two aims: (1) to identify the internal differences influencing the path of reorganizations versus liquidation of failed SMEs, allowing a diagnosis of the firmt's economic and financial situation in order to prevent its disappearance; and (2) to recognize significantly internal differences between reorganized outof-court and those reorganized in-court. Specifically, our results reveal that the ability of the firm to create value and to manage the receivable and working capital financial design and the level of historical slack contribute to understand the differences between SMEs that are able to overcome difficult situations and survive of those that are liquidated. In addition, our results also reveal that the level of assets and debts are the main difference between firms that opt for an out-of-court reorganization and those that follow a judicial reorganization process.

(C)2021 ASEPUC. Published by EDITUM - Universidad de Murcia. This is an open access article under the CC BY-NC-ND license (http://creativecommons.org/licenses/by-nc-nd/4.0/).

Supervivencia de las pymes en situación de "Fracaso Empresarial" y reorganización extrajudicial versus judicial: factores explicativos internos

\author{
RES U M EN
}

Los contenidos de la Directiva (UE) 2019/1023 de 20 de junio de 2019 sobre marcos de reestructuración preventiva, han puesto de relieve la necesidad de evaluar, con suficientes elementos de juicio, las posibilidades de reestructuración de empresas insolventes, pero viables a futuro. En este sentido, la presente investigación se apoya en la Teoría de los Recursos, para tratar de identificar aquellos factores internos que contribuyen a explicar la diferencias en el resultado que experimentan las PYMES después de haber sufrido una situación de "fracaso empresarial", en un sentido amplio del término. Para ello, se ha utilizado una muestra de 6.285 PYMES españolas fracasadas en el período 2008-2010 y se observa la evolución de cada una de ellas durante el período 2011-2013. Los objetivos de investigación son: (1) identificar las diferentes características internas de las empresas con dificultades financieras que influyen significativamente en que se produzca su reorganización frente a que opten por liquidarse, lo que permite establecer un diagnóstico de la situación económica y financiera de este tipo de empresas para prevenir su desaparición; y, (2) reconocer características internas significativamente diferentes entre las empresas reorganizadas extrajudicialmente y las reorganizadas judicialmente. Nuestra investigación responde a la llamada sobre la realización de estudios que analicen la heterogeneidad entre el comportamiento de las PYMES, en especial, en entornos críticos. En particular, nuestros resultados revelan que la capacidad de la empresa para crear valor, y para llevar a cabo una buena gestión financiera de las cuentas por cobrar y del capital circulante, así como del volumen de resultados acumulados de ejercicios anteriores, contribuyen a comprender las diferencias entre las PYMES que son capaces de superar situaciones difíciles y sobrevivir, de aquellas que se encuentran en fase de liquidación. Además, nuestros resultados también revelan que tanto el nivel de activos como el de deudas son las principales diferencias entre las empresas que optan por una reorganización extrajudicial y las que siguen un proceso de reorganización judicial.

(C)2021 ASEPUC. Publicado por EDITUM - Universidad de Murcia. Este es un artículo Open Access bajo la licencia CC BY-NC-ND (http://creativecommons.org/licenses/by-nc-nd/4.0/). 


\section{Introduction}

It is widely known that small and medium-sized enterprises (SMEs) dominate the economies of most countries, contributing to employment and gross domestic product. For example, in the European Union, SMEs made up $99.8 \%$ of all enterprises (23 million SMEs), $57.4 \%$ of value added (3.9 trillion), and $66.8 \%$ of employment ( 90 million people) in 2015 (European Commission, 2016). Therefore, the role this type of company plays in contrast to large companies is clear. Despite their importance in the global business environment, SMEs support greater levels of pressure that affect their performance (Jacob, Julien, \& Raymond, 1997) and increase their vulnerability and risk of failure (St-Pierre, 1999) and/or bankruptcy (Carter \& Van Auken, 2006). The literature on SMEs has argued that these firms face barriers, such as access to financing resources (Freear, Sohl, \& Wetzel, 1995; Mutezo, 2013; Kraemer-Eis, Lang, \& Gvetadze, 2015), difficulty in finding skilled staff or experienced managers (Fraser, Storey, Frankish, \& Roberts, 2002), high competition, high production costs, and regulations concerning customers (European Commission, 2014, p. 26), insufficient knowledge to enter international markets (Mulling, Silveira, Dutra, \& Lauren, 2015), a lack of benefits derived from scale effects (Aldrich \& Auster, 1986; Audretsch \& Mahmood, 1994), and scant diversification (Geroski, Mata, \& Portugal, 2010), among others. These barriers make it difficult to cope with and overcome a crisis event (Geroski et al., 2010). Empirically, it has also been demonstrated that SMEs have a lower probability of survival than larger firms (Mitchell, 1994; Sharma \& Kesner, 1996; Box, 2008). In fact, during the most recent global economic and financial crisis, SMEs suffered higher rates of failure than large firms (Organisation for Economic Co-Operation and Development OECD, 2009).

Despite the consequences that crises may have for the sustainability of SMEs, a crisis event need not necessarily lead to the death of the firm. According to Carmeli and Schaubroeck (2008, p. 192), crises may offer "an opportunity to redesign and restructure a faulty system and turn it into a better one". In fact, the economic literature asserts that SMEs have greater flexibility (Kuratko, Goodale, \& Hornsby, 2001; Kraus, Moog, Schlepphorst, \& Raich, 2013) and less formal structures (Hill \& Wright, 2001) - aspects that entail less rigidity in decision-making (Carlsson, 1999) and could facilitate the introduction of changes. This context suggests that SMEs characteristics could favour reorganization, reducing the risk of failure after a crisis event. In addition, some studies note the influence of bankruptcy and reorganization laws on the reorganization process of SMEs (see, among others, Peterson, Kozmetsky, \& Ridgway, 1983; Dewaelheyns \& Van Hulle, 2008). The insolvency laws provide tools to balance the rights of the various participants in the process, mainly debtors and creditors; thus, the proper functioning of the insolvency system helps to prevent the liquidation of viable firms. In this regard, researchers have studied the efficiency of bankruptcy laws in preventing the premature liquidation of viable firms in different countries (Franks \& Torous, 1989; Easterbrook, 1990; Couwenberg \& De Jong, 2008). However, according to Claessens and Klapper (2005), the specific design features of insolvency regimes influence the use of judicial procedures vs. out-of-court reorganizations. For example, firms can be reorganized through recapitalization - an exchange of equity for debt. Because creditors could suffer losses, the degree to which the creditor is willing to recapitalize depends on the ability of the judicial procedures to protect their rights. We might expect that the economic and financial characteristics of a failed firm provide creditors with indications with which to assess the possibilities of achieving their aims, choosing between a judicial procedure or an out-of-court reorganization.

Previous studies in the field of SME failure have been fundamentally oriented to compare distressed with nondistressed firms. However, there are a limited number of insights into the reorganization processes (see, among others, Jacobs, Karagozoglu, \& Layish, 2012; Camacho-Miñano, Segovia-Vargas, \& Pascual-Ezama, 2015; Mayr, Mitter, \& Aichmayr, 2017). To our knowledge, although several researchers identify management inability as the main cause of SME failure (Argenti, 1976; Berryman, 1983; Perry \& Pendleton, 1984; Peacock, 1985; Laitinen \& Gin Chong, 1999; Day, 2000), there has been little research on the internal factors that enable reorganization. Because the success or failure of SMEs generate social and economic implications that are of interest to all levels of society (owners and family, employees, customers, and suppliers) (Carter \& Van Auken, 2006), it is important to identify the factors that enable crises to be addressed and overcome, allowing firms to survive in risky environments. This question has been revealed as important if we consider the economic and financial difficulties of recent years, which have generated instability, especially affecting SMEs. In this sense, a greater understanding of SMEs' reorganization process is needed to prevent these firms' disappearance and provide stakeholders with enough information to implement their risk decisions and the appropriate measures in each case. We hypothesize that differences in the internal characteristics of firms affect the path taken to resolve financial distress (reorganization vs. liquidation).

Moreover, Kraaijenbrink, Spender, and Groen (2010) call for research to explain the differences among firms' outcomes, following the approaches of the resource-based theory. In that respect, more research is needed on the extent to which SMEs could use out-of-court vs. in-court reorganization to overcome financial distress (Blazy, Martel, \& Nigam, 2014). In previous literature, the choice between out-of-court negotiations and in-court proceedings is linked to strong creditor rights and greater judicial efficiency (Claessens \& Klapper, 2005). In the Spanish context, despite the latest reforms to the bankruptcy law, which had making the system more efficient as its main aim, there is evidence about the scarce use of in-court reorganization (García-Posada \& Mora-Sanguinetti, 2013), linking this behaviour to factors such as the stigma generally associated with insolvency proceedings in Spanish society or the poor perception of the efficiency of the system compared with alternative mechanisms to overcome financial problems. In addition, some researchers indicate that the main factors explaining the use of the in-court reorganization process are linked to differences in firms' financial structure (see, among others, Gilson, John, \& Lang, 1990; Asquith, Gertner, \& Scharfstein, 1994). Those studies were conducted for large firms. However, according to Beck, Demirgüç-Kunt \& Maksimovic (2008), SMEs' financial patterns are different from large firms. To the best of our knowledge, the extent and nature of the influence of firms' internal characteristics on the choice of reorganization processes of financially distressed firms has not yet been analysed for a sample of SMEs. This study contributes to filling this gap. Indeed, our understanding of the business failure of SMEs indicates that the internal characteristics of the firm (financial and economic) could also influence the options for out-of-court negotiation. Accordingly, we expect that the internal characteristics of SMEs influence firms' options when choosing between out-of-court vs. in-court reorganization. 
Specifically, our research addressed the following research questions: Are the internal characteristics different in financially distressed firms that are eventually reorganized or liquidated? Are the internal characteristics different among out-of-court or in-court reorganized firms?

Drawing on resource-based formulations, we analyse the internal factors that contribute to explaining the different paths followed by SMEs when they suffer a crisis. In doing so, we used a sample of 6,285 unsuccessful Spanish SMEs for the 2008-2010 period and observed the evolution of each SME during the 2011-2013 period. We investigated a simple accounting-based framework that allowed us to achieve two objectives: (1) to identify the different internal characteristics that significantly influence the path of reorganization versus that of liquidation of the financially distressed SMEs, allowing a diagnosis of the firm's economic and financial situation to prevent its disappearance; and (2) to recognize significantly different internal characteristics between firms reorganized out-of-court and those reorganized in-court. Our investigation lends further support to the call for more studies that analyse heterogeneity among the behaviours of SMEs, particularly in critical environments (Blazy et al., 2014; Kraaijenbrink et al., 2010). Specifically, our results reveal that the ability of the firm to create value and to manage the receivable and working capital financial design and the level of historical slack - "the difference between the payments required to maintain the organization and the resources obtained from the environment by the coalition" (Cyert \& March, 1963, p. 278-279) - contribute to understanding the differences between SMEs that are able to overcome difficult situations and survive and those that are liquidated. In addition, our results also reveal that the levels of assets and debt are the main difference between firms that opt for an out-of-court reorganization and those that follow a judicial reorganization process.

This research contributes to the bankruptcy literature with respect to SMEs - by examining the different internal resources and capabilities that cause a company to undertake reorganization instead of undergoing liquidation. The obtained results could be useful to SMEs in other contexts, given the importance of this type of firm for most countries' economies. Furthermore, internal factors of the companies that influence the choice between out-of-court or in-court reorganization have been revealed - aspects that, until now and to the extent of our knowledge, have not been studied in the literature with regard to SMEs.

The article is structured as follows. In the next section, literature about the reorganization processes is presented. After this review, the next section describes the data, variables and methodology. The third section discusses the results of the statistical models. Finally, the last section presents the discussion and conclusions.

\section{Literature review and research questions}

\subsection{Internal resources and the likelihood of failed SMEs to opt for reorganization}

Business failure is a broad concept that includes a variety of states that can negatively impact companies' long-term sustainability. Some studies even describe business failure as a process (see, among others, Laitinen, Lukason, \& Suvas, 2014; Lukason \& Hoffman, 2014; Lukason, Laitinen, \& Suvas, 2016). In generic terms, three different states of failure have been differentiated (Altman, 1983): economic failure, financial failure (or technical insolvency) and bankruptcy. A firm is undergoing economic failure when income is insufficient to cover the costs over a long period of time. Financial failure occurs when the firm cannot meet its current obligations when they are due (Blazy et al., 2014), so the company is in a state of a lack of liquidity. These two concepts are considered transitory situations, and if the situation were chronic, the firm would be in bankruptcy. Bankruptcy is identified as the existence of negative net equity, as the value of the liabilities exceeds the value of the assets. This last concept has been identified as the step prior to the beginning of the legal procedure (established for that purpose in the legislation of each country $^{1}$ ) with the objective of solving the financial problems (reorganization) or starting the liquidation process (Mayr et al., 2017).

Reorganization processes start from learning and understanding the mistakes the company made in the past (Mayr et al., 2017), taking into account that "failure is an essential prerequisite for learning" (Sitkin, 1992, p. 232). To this end, SMEs must review the way they managed their business - feedback information (Shepherd, 2003), among other things, in relation to the following (Ucbasaran, Shepherd, Lockett, \& Lyon, 2013, p. 183): "issues surrounding the management of cash and investment; managing internal and external stakeholder relationships; building and managing partnerships; managing the challenges of growth; and understanding the marketplace and competition". All these measures have the ultimate objective of regaining a competitive advantage or position in the market (Mayr et al., 2017). Accordingly, and in line with the above objective, the resource-based view is applicable because sustained competitive advantage is derived from the resources and capabilities that a firm can control and that are valuable, rare, imperfectly imitable, and not substitutable (Barney, 1991). Although the resources are identified with all factors that the company has or can control, the capabilities are defined as "information-based, tangible or intangible processes that are firm-specific and are developed over time through complex interactions among the firm's resources" (Amit \& Schoemaker, 1993, p. 35). Therefore, not only must the company have the necessary resources, but it must also have the capacity to organize those resources, allowing it to improve their effectiveness and efficiency; thus, it is vitally important that these resources are managed adequately. Based on the fact that one of the main internal causes of business failure is the inadequate (incompetent or inefficient) management of resources (Peterson, et al., 1983; Kharbanda \& Stallworthy, 1985; Laitinen, 1991; Gaskill, Van Auken, \& Manning, 1993; Zimmerer \& Scarborough 1994; Allen, 1995; Hodgetts \& Kuratko, 1995; Thornhill \& Amit, 2003), if changes are not introduced as a result of learning from mistakes, the company will not be able to reorganize and survive.

On the empirical level, over the years, different studies have analysed the (internal and external) factors that could affect the possibilities to restructure business failure. Among the first studies conducted, the work of Lopucki (1983) is noteworthy. He highlights size and the activity sector as being the most significant variables in business restructuring, while on the other hand, factors such as company age, geographical situation and the existence of opposition by creditors are not deemed to be significant. Using probit analysis,

${ }^{1}$ For more information, see Nigam and Boughanmi (2017), who analyse the reforms introduced in insolvency framework for various countries from 2005 to 2013. 
Casey, McGee, and Sticney $(1986)^{2}$ find two factors that had significant discriminating power between bankrupt firms that successfully reorganize from those that liquidate: the proportion of assets not secured or pledged and the change in profitability in the years preceding bankruptcy. Campbell (1996), using a prediction probit model, concludes that the following factors influence the likelihood of business reorganization: greater size, higher return on assets, the existence of a reduced number of secured creditors, fewer assets offered as collateral, fewer secured creditors below the amount of debt and the type of business.

Following the aforementioned pioneering research on the subject, many other studies have followed, studying the relationship between different internal factors and the likelihood that distressed firms will be reorganized instead of liquidated (Kim \& Kim, 1999; Routledge \& Gadenne, 2000; Bryan, Tiras, \& Wheatley, 2002; Jacobs, Karagozoglu, \& Layish, 2008; Jacobs et al., 2012; Wang, 2012; Camacho-Miñano et al., 2015). However, many of these studies on corporate restructuring have focused on larger companies. Consequently, research on this topic for small (unlisted) companies is scarce. However, the work by Camacho-Miñano et al. (2015) is worth mentioning. Their results show that larger firms (measured by asset value) among the SMEs entering the bankruptcy process with high liquidity and ROA are more likely to remain in operation in the future. For their part, with a sample of all firms (393 SMEs) that filed for bankruptcy in the Federal State of "Upper Austria" in 2004, and following the resourcebased view, Mayr et al. (2017) conclude that strategic repositioning and the type of industry are factors that positively impact reorganization likelihood, marketing and firm age negatively impact it, and the location of SMEs does not impact sustainable reorganization. bankrupt firms that successfully reorganize from those that liquidate Using probit analysis, two factors were found to have significant discriminating power: the proportion of assets not secured or pledged at the bankruptcy filing date (referred to as the free assets percentage) and the change in profitability in the years preceding bankruptcy. Using probit analysis, two factors were found to have significant discriminating power: the proportion of assets not secured or pledged at the bankruptcy filing date (referred to as the free assets percentage) and the change in profitability in the years preceding bankruptcy. Using probit analysis, two factors were found to have significant discriminating power: the proportion of assets not secured or pledged at the bankruptcy filing date (referred to as the free assets percentage) and the change in profitability in the years preceding bankruptcy. In recent years, new approaches to the study of business reorganization have emerged. Using the stakeholder theory approach and considering that stakeholder relationships are an essential component of corporate reorganization, Mayr (2015) analyses a real case of corporate restructuring and concludes that successful reorganization requires both sustainable collaboration with stakeholders and the resolution of conflicts of interests.

Most researchers on the study of the internal factors influencing the probabilities of reorganization versus the liquidation of financially distressed firms have identified profitability, liquidity, solvency, leverage and economic structure as

${ }^{2}$ Casey et al. (1986) develop multivariate prediction models to empirically prove the hypotheses outlined by White $(1981,1983)$ regarding the factors that enable differentiation between the companies that were successfully reorganized and those that were liquidated once they had initiated a bankruptcy process. White $(1981,1983)$ considers the existence of assets not offered as guarantee of debts, firm size, the prospective benefits and the participation of management in the capital of the company as being decisive factors in business reorganization. the main influencers of the survival or otherwise of those firms. First, greater profitability implies a higher intrinsic value of the firm (Jacobs et al., 2008), as these firms can generate funds internally, thereby also increasing their likelihood to be able to borrow externally (White, 1983). Therefore, it is expected that greater profitability positively impacts the likelihood of reorganization, as some previous studies have demonstrated (Casey et al., 1986; Campbell, 1996; Camacho-Miñano et al., 2015). Second, regarding liquidity, no clear relationship has been defined by previous research. On the one hand, logic would suggest that firms with greater liquidity are in a more advantageous position to continue their activity (Jacobs et al., 2008) and therefore be reorganized rather than liquidated. On the other hand, some research notes that liquidity could be seen by creditors as a resource from which they might recover their credit, so they could put pressure on distressed firms that have greater liquidity to opt for bankruptcy (Fisher \& Martel, 1995). In fact, although some empirical studies have found that more liquid firms are more likely to be reorganized (Routledge \& Gadenne, 2000; Bryan et al., 2002; Camacho-Miñano et al., 2015; Cultrera \& Bredart, 2016), others have shown the contrary relationship (Jacobs et al., 2012; Wang, 2012). Third, the solvency of firms has been positively related to firm reorganization (Bryan et al., 2002; Rose-Green \& Lovata, 2013). That is, greater solvency is linked to a better capability of the firm to access new credit with which to overcome financial difficulties because creditors perceive that these loans will be repaid in time. Fourth, firm leverage is predicted to positively or negatively affect the likelihood of reorganization (RoseGreen \& Lovata, 2013). On the one hand, the predominance of creditors' bargaining power is linked to a greater likelihood of reorganization (Jacobs et al., 2008), and in fact, some empirical studies have detected this positive relationship (Jacobs et al., 2012; Rose-Green \& Lovata, 2013). On the other hand, if creditor coordination problems exist, difficulties in achieving agreement are likely to occur, and the reorganization process will be further complicated by managers' inability to obtain additional funds to conduct a reorganization process (Routledge \& Gadenne, 2000). Fifth, with regard to the firm's economic structure, the firm's free cash flow and its intangible assets appear to be the most important assets to assist in overcoming financial difficulties. That is, the level of cash flow is linked to the firm being in a better position to restructure its capital and, consequently, is expected to be positively related to the likelihood of reorganization (Jacobs et al., 2008). Additionally, greater levels of intangible assets could positively affect firm reorganization because, in the case of liquidation, these assets (human capital, research and development, among others) could lose their value (De Miguel \& Pindado, 2001). This positive relationship has been demonstrated by Jacobs et al. (2008).

In accordance with the above, this study considers several accounting ratios as proxies for internal economic and financial factors (profitability, liquidity, solvency, leverage and economic structure), which have been identified in the literature as being relevant to explaining the likelihood of financially distressed firms to opt for reorganization.

\subsection{Out-of-court vs. in-court reorganization of failed SMEs}

As an alternative to liquidation, the company could carry out a reorganization (under legal procedure or following informal or outside-of-court private settlements). This concept 
is understood as the process that has the objective "to enable the financially troubled firm to continue in existence and maintain whatever goodwill it still possesses, rather than to liquidate its assets for the benefit of its creditors" (Altman \& Hotchkiss, 2006, p. 8). Although the costs of reorganization depend on firm size, the complexity of the case, and the ability of the bankrupt firm to pay (Fisher \& Martel, 1995), various empirical studies (Gilson et al., 1990; Betker, 1997) have demonstrated that informal or out-of-court reorganization is less costly (directly and indirectly) than formal bankruptcy proceedings (see, among others, Roe, 1983; Jensen, 1989; Fisher \& Martel, 1995). These cost savings, together with the fact that the out-of-court procedure is considered to be quicker than the legal process (Garrido, 2012; Blazy et al., 2014), make this solution the most recommendable. Moreover, out-of-court reorganization enables the process to be treated confidentially, preserving the image of all participants in the negotiation (both distressed firms and creditors) (Franks \& Torous, 1989; Chatterjee, Dhillon, \& Ramírez, 1996; Blazy et al., 2014). Other advantages of carrying out an out-of-court reorganization exist, including the following (see Table 1) (Garrido, 2012): in the absence of formal procedures, it may be easier to carry out the negotiation between the parties and to take into account the particular needs of each of the debtors; following a private process, the company can avoid damage to its reputation that may bring about legal and public proceedings; furthermore, the debtor's management remains in place and there are no formal controls of their activity.

Table 1

Advantages and disadvantages of out-of-court reorganization

\begin{tabular}{ll}
\hline \multicolumn{1}{c}{ ADVANTAGES } & \multicolumn{1}{c}{ DISADVANTAGES } \\
\hline - Flexibility and ease of adaptation to the & - Analysis of the debtor's situation \\
specific needs of the debtor's business. & - Punishment of fraudulent behaviour \\
- Ease of negotiation & - Avoidance actions \\
- Timing issues & - Availability of different remedies \\
- Confidentiality & - Lack of unanimity requirement \\
- Less stigma than formal insolvency & - No requirement of debtor's consent \\
- Continuation of the debtor's business & - Fewer chances of lender liability actions \\
- No changes in management & - Difficulties of multi-party negotiations \\
- No changes in the rights of the parties & - Directors' liability \\
- No court involvement & - Existence of a formal reorganization \\
- Lower costs & procedure \\
- Lack of regulatory impact & - Recognition by foreign courts \\
\hline
\end{tabular}

Source: Own elaboration based on Garrido (2012)

Despite the advantages presented by out-of-court versus in-court organization, some empirical studies have revealed that the number of companies that follow an out-of-court reorganization is no different from the number that adopt an incourt procedure (Franks \& Torous, 1989; Gilson et al., 1990; Yost, 2002) or even that the percentage of companies that follow the legal procedure is greater than 70\% (Jacobs et al., 2012; François \& Raviv, 2017). At the theoretical level, the preference for formal reorganization by companies is based on the existence of asymmetric information and creditor conflicts (Jostarndt \& Sautner, 2010; Garrido, 2012; François \& Raviv, 2017). First, asymmetric information between debtors and creditors can lead to companies undergoing legal reorganization because in legal procedures, this asymmetricity is mitigated because an inventory of assets is drawn up that overcomes the opacity of the situation of the company presented by the entrepreneur/owner (Chen, 2003; Garrido, 2012; François \& Raviv, 2017). Second, when companies have multiple creditors, it is more difficult to achieve a unanimous consensus among them all (Garrido, 2012; François \& Raviv, 2017) because not all lenders have similar incentives (Gertner \& Scharfstein, 1991). In addition, there may also be greater conflicts or lack of agreement between private and public lenders that make it difficult to carry out an outof-court reorganization (Gilson et al., 1990; Asquith et al., 1994).

However, as we posit above, in Spain, most firms resort to out-of-court procedures (García-Posada \& Mora-Sanguinetti, 2013). Reasons for choosing out-of-court reorganization could include the state of a firm's internal resources and financial structure (see, among others, Gilson et al., 1990; Asquith et al., 1994). In fact, according to Boyle and Desai (1991), most business failures arise due to "internal factors affected by managerial action and discipline", such as "failure to control operational costs and failure to analyze financial statements". While to date, there is no evidence for Spain, according to previous literature, some internal factors are likely to make out-court reorganization feasible for distressed firms. In particular, profitability is positively related to the probability of an out-of-court reorganization of distressed firms. There is some empirical evidence about this relationship (Yost, 2002; Jostarndt \& Sautner, 2010; Jacobs et al., 2012). Because firms with greater profitability may be able to generate more cash flows in the future to address their debts (Yost, 2002; Blazy et al., 2014), creditors, aware of this circumstance, are willing to negotiate with the debtor. Additionally, liquidity has been recognized to influence the in-court vs. out-of-court reorganization dilemma. However, evidence in this respect presents contradictory arguments. Although firms with higher liquidity may be in better positions to carry out an out-of-court process, the existence of inherent conflicts of interest between debtors and creditors could affect this process. This effect is not surprising if creditors deem that the in-court reorganization process provides strong protection of their rights. In fact, empirical evidence has been found concerning the negative influence of firm liquidity on the probabilities of out-of-court reorganization (Jacobs et al., 2008). Additionally, evidence regarding the potential role of leverage is offered by various studies. These studies have indicated that firms with higher leverage and long-term debt are less likely to follow an in-court reorganization process, attempting to resolve the financial distress privately (out-ofcourt) (Yost, 2002; Blazy et al., 2014). Studies have also established that firms with greater debt owed to banks and fewer lenders tend to follow out-of-court procedures to restructure their distressed debt (Gilson et al., 1990). Another important internal resource in the context of complex phenomena such as financial distress is the level of intangible assets of a firm. As Jacobs et al. (2008) note, these types of assets could lose their value as a consequence of an in-court process, and creditors and debtors may prefer an out-of-court reorganization to protect their value. This argument is supported by the results obtained by Gilson et al. (1990).

\section{Data and methods}

\subsection{Sample and data}

This study uses firm-level data from the Sistema de Análisis de Balances Ibéricos (SABI) database. The SABI contains data for Spanish firms in a cross-sectional format, providing an important source of information for our study. This dataset has been widely used by previous literature on firms' financial distress (see, among others, Madrid-Guijarro, GarcíaPérez-de-Lema, \& Van Auken, 2011; Camacho-Miñano et al., 2015) and performance (see, among others, García-Pérezde-Lema, Alfaro-Cortes, Manzaneque-Lizano, \& BanegasOchovo, 2012) and is recognized as providing a good repres- 
entation of the Spanish context (Almunia, López-Rodríguez, \& Moral-Benito, 2018).

We first identify all the companies that were in situations of financial distress as well as those that had had consecutive operating losses for at least three consecutive years (Economic failure) (following Flagg, Giroux, \& Casper, 1991) and those with negative equity for three consecutive years (Financial failure) (see among others Pastena \& Ruland, 1986) $(8,675$ financially distressed firms during the years 2008-2010) (see Table 2). We use a broad concept of financial distress because, according to previous studies, there are companies that suffer from financial or economic distress years before bankruptcy (Fitzpatrick, 1924) - most of which never start a legal process of failure. In doing so, we avoid one of the main problems related to a bankruptcy criterion. Specifically, due to the diversity of the business failure process (Laitinen, 1991), bankruptcy does not capture the complete reality of firm failure (Jones \& Hensher, 2007), as some incidences of firm failure do not lead to bankruptcy. In addition, as our main aim is to analyse the characteristics of the firms that have the possibility of survival when they suffer a failure (via reorganization), it is necessary that we expand the concept of failure beyond that of bankruptcy. In fact, the bankruptcy process in Spain usually begins when the firm is already in a very difficult financial and economic situation, so only very few firms survive (approximately 2\% for 2010 according to the National Statistics Institute of Spain, taken from Camacho-Miñano et al., 2015; 1.01\% in 2016 according to the Informa Report on the liquidations process in Spain). The choice of the study period has allowed us to have a greater number of failed companies in the analysis. However, although the period coincides with the economic crisis, no adjustments have been made to the model to correct this situation because, as Campillo, Serer, and Ferrer (2013) have shown, prediction models are as valid for periods of crisis as they are for periods of no crisis in the Spanish context.

Once failure was detected, the sample was filtered. Specifically, we apply three filters. First, we filter by the arithmetic and logical coherence of the accounting statements information to avoid accountant information errors. These are the filters applied by the Spanish Mercantile Register to the accounts deposited through the computer system, and they are known as tests of primary errors or primary arithmeticlogical controls. In all them, a variation of $+/-1$ has been allowed to cover the problems that could be caused by rounding up. Second, we also discriminate those firms with illogical or zero value for the variables under study, which are accounting ratios. Third, we filter the sample for statistical outliers, that is, ratio values above 2.5 times the typical deviation (López, Gandía, \& Molina, 1998). After that process (2,390 firms were discarded by the aforementioned filters; see Table 2), a total of 6,285 unsuccessful Spanish companies for the period 2008-2010 were found (see Table 2). Due to the reform of the Spanish accounting rules in 2007, we chose the following period to overcome problems related to a lack of comparability in the accounting information. To identify their future situation, we observed the evolution of the firm during the 2011-2013 period. Therefore, unsuccessful companies were able to act in different ways, and consequently, their outcomes would also differ. Accordingly, we identified whether the firm has changed its economic and financial situation and remains a healthy firm without operative losses and/or negative equity for the period from 2011 to 2013 (outof-court reorganization), was or is currently being liquidated (liquidation) or is in a formal reorganization process (in-court reorganization). The reorganized firms (healthy firms from
2011 to 2013 without losses and/or negative equity) were classified as out-of-court reorganization if they had not started in-law reorganization proceedings and remained healthy during the period 2011 to 2013. Therefore, the sample on which we will work in this study will be composed of the representative sub-samples of the different outcomes of business failure (see Table 2).

\section{Table 2}

Sample selection process and description

\begin{tabular}{|c|c|c|}
\hline Panel A. Sample selection process (2008-2009-2010) & & Number of firms \\
\hline Financial distress observations in the SABI dataset & & 8,675 \\
\hline $\begin{array}{l}\text { Less: Observations with incomplete or missing data } \\
\text { and outliers }\end{array}$ & & 2,390 \\
\hline Final financial distress observations & & 6,285 \\
\hline $\begin{array}{l}\text { Panel B. Final sample by financial distress outcome } \\
(2011,2012,2013)\end{array}$ & Frequency & $\%$ \\
\hline Liquidation & 102 & 1.62 \\
\hline Out-of-court reorganization & 3,130 & 49.80 \\
\hline In-court reorganization & 3,053 & 48.58 \\
\hline Total & 6,285 & 100 \\
\hline
\end{tabular}

* Data taken from the SABI database during the 2008-2010 period. Those firms with consecutive operating losses and/or negative equity during those three years are considered failed firms $(6,285)$. Those firms that were identified as failed during 20082010 were observed during 2008-2011. We clarified them as follows: (1) "liquidation" if a firm has applied for a liquidation process during the period from 2011 to 2013 ; (2) "in-court reorganization" if a firm has applied for an in-court reorganization process during the period from 2011 to 2013; (2) "out-of-court reorganization" if a firm remains healthy during the period from 2011 to 2013 , that is, it overcomes the failure situation.

\subsection{Dependent variable: Failure outcome}

There are three possible financial distress outcomes taken into consideration in our study: (1) Out-of-court reorganization, where the firm overcomes financial and economic difficulties without any help from legal procedures; (2) In-court reorganization, where the firm overcomes financial and economic difficulties with the help of legal procedures; (3) Liquidation, where the firm does not overcome its financial and economic difficulties and winds up its assets, that is, they are sold and the proceeds are used to repay as many creditors as possible. Along these lines, we follow other previous studies that employ a similar stratification of the dependent variables. As an example, Pastena and Ruland (1986) include, as possible failure outcomes, the reconstruction, the continuation in the business failure situation and the liquidation or absorption of the firm.

\subsection{Independent variables}

Following the theoretical outline discussed above, we have used a wide range of accounting ratios related to profitability and cost, the economic structure, the financial structure, solvency and liquidity, the results structure, value added and productivity. Specifically, an initial group of variables, made up of thirty-eight ratios and three representative variables of size, the industrial sector and the antiquity, was chosen (See Annex 1). We chose those variables based on previous literature on SMEs' business failure and business failure outcomes (see, among others, Pastena \& Ruland, 1986; Gilson et al., 1990; Lizarraga, 1997; Laitinen \& Gin Chong, 1999; Abad, Arquero, \& Jiménez, 2003; Altman \& Sabato, 2007; Keasey, Pindado, \& Rodríguez, 2015; Filipe, Grammatikos, \& Michala, 2016; Lukason et al., 2016). In addition, we used a methodology based on a "Forward Wald" process (see next section) to identify the most significant variables with which to distinguish between each financial distress outcome (outof-court reorganization, in-court reorganization and liquidation), following the aims of this study and filling the research 
gap described above. In this context, it is necessary to be aware that the use of accounting data has been questioned previously, especially in situations of failure, since manipulation may be suspected (García, Osma and Neophytou, 2009; Bisogno \& De Luca, 2015). However, accounting manipulation is a risk that exists and that can also affect large listed companies (Amat et al., 2004). Therefore, no accounting information has a total guarantee of quality (Gómez et al., 2008). Several empirical studies in the Spanish context have demonstrated that the quality of information provided by small companies is no lower than that provided by larger firms (Alemany \& Monllau, 1997; López et al., 1998). In addition, regarding its impact on the consistency of statistical results and according to Labatut et al. (2009), the information provided by SMEs is valid for research purposes and for obtaining consistent results. Moreover, according to Spanish accounting law, all firms must deposit their financial statements in the dataset of a public body so that they are available for all stakeholders. This process guarantees the transparency and reliability of the data, notwithstanding the possibility of some mistakes. In fact, various studies in Spain focusing on failed SMEs (Madrid-Guijarro et al., 2011; García-Pérez-de-Lema et al., 2012) have used accounting ratios to test their hypotheses. We follow the sample selection process of those studies and use accounting information from the SABI dataset to test our research questions.

\subsection{Methodology}

To test our research questions and following previous research in the field of study, we used a logistic regression (Ohlson, 1980; Ló, 1986; Barniv, Agarwal, \& Leach, 2002; Gallego \& Gómez, 2002). Specifically, due to the categorization of our dependent variable into three categories, we apply a multinomial logit technique. This methodology allows us a) to work with several categories of the dependent variables (out-of-court reorganization, in-court reorganization, and liquidation) and b) to use as independent variable ratios with a distribution different from the normal one. Dependent polychotomic variables that we will denominate generically as the "failure outcome" are specified in the following way:

$Y_{i}=0$ if firm "i" was considered to be undergoing outof-court reorganization.

$Y_{i}=1$ if firm "i" was considered to be undergoing incourt reorganization.

$Y_{i}=2$ if firm "i" was considered to be undergoing liquidation.

The three categories of the endogenous variable are denoted as $\mathrm{J}=1,2$ and 3 .

The model of estimation of the "failure outcome" variable follows a model of probability that can be expressed generically in the following way:

$$
P\left(Y_{i}=J\right)=\frac{e^{\beta_{j} X_{i}}}{\sum_{k=1}^{3} e^{\beta_{k} X_{i}}}
$$

where $X_{i}=\left(\begin{array}{c}X_{i 1} \\ \cdot \\ \cdot \\ X_{i N}\end{array}\right)$ is an N-dimensional vector where the value of each firm for the variable $\mathrm{N}$ determines the probability of the same one belonging to a specific state. On the other hand, $\beta_{J}=\left(\begin{array}{c}\beta_{J 1} \\ \cdot \\ \cdot \\ \beta_{J N}\end{array}\right)$ contains the population parameters of the model that are obtained from the sample values and that define the relation between the "failure outcome" variable and the $\mathrm{N}$ explanatory variables.

The estimation of the parameters is carried out following maximum likelihood estimation, and we standardize with respect to the "Liquidation" resolution so that it is assumed that the vector $\beta_{1}=\left(\begin{array}{l}0 \\ \cdot \\ \cdot \\ 0\end{array}\right)$ and therefore the system to be considered would be the following:

$$
\begin{gathered}
P\left(Y_{i}=J\right)=\frac{e^{\beta_{j} X_{i}}}{1+\sum_{k=0}^{1} e^{\beta_{k} X_{i}}}, J=0,1 \\
P\left(Y_{i}=0\right)=\frac{1}{1+\sum_{k=0}^{1} e^{\beta_{k} X_{i}}}
\end{gathered}
$$

Then, the function of probability to maximize is

$$
\ln (L)=\sum_{i=1}^{T} \sum_{J=1}^{3} d_{i J} \ln \left(\operatorname{Prob}\left(Y_{i}=J\right)\right)
$$

where $d_{i J}=1$, if company 1 belongs to category $\mathrm{J}$, and $d_{i J}=$ 0 , otherwise, with $\mathrm{T}$ representing the sample size.

The results defined two different functions, one for each of two contemplated alternatives, where the reference category is "liquidation". Therefore, $\mathrm{P}\left(\mathrm{Y}_{\mathrm{i}}=0\right)$ indicates the probability that firm "i" is subject to out-of-court reorganization having liquidation as the alternative, whereas the function $\mathrm{P}\left(\mathrm{Y}_{\mathrm{i}}=1\right)$ indicates the probability that firm "i" is in an in-court reorganization rather than a liquidation process.

The selection of variables follows the "Forward Wald" procedure, according to which variables are included in the model one-by-one, avoiding multicollinearity problems; for this reason, the correlation between variables is not an important issue in our study.

\section{Results}

\subsection{Descriptive analysis}

Table 3 (Panel A) presents the means, quartiles and standard deviations of the independent variables under study for the 2008-2010 period, for which we have identified a situation of financial distress. The mean of the ratios reveals the difficulties that the SMEs under study are suffering. In this sense, many ratios present negative values, particularly those related to profitability and cost as well as solvency and liquidity. The majority of the firms are between 6 and 19 years old. The most common activity sector is services.

Next, Table 3 (Panel B) shows the descriptive analysis for one year before outcome, distinguishing between outof-court reorganization, in-court reorganization and liquidation. The mean differences test for the three groups revealed significant differences between at least two groups in most cases. The worst economic and financial situations are shown for liquidated firms, as we expected. However, we also observe that in-court reorganization firms present some economic and financial weaknesses, corroborating the observation that companies initiate this process in worse conditions than those that opt for an out-of-court restructuring. 
Table 3

Descriptive analysis. Panel A 2008-2010 (Business failure)

\begin{tabular}{|c|c|c|c|c|c|c|}
\hline \multirow{2}{*}{\multicolumn{3}{|c|}{ Continuous variables }} & \multicolumn{4}{|c|}{ Average $2008-2010$} \\
\hline & & & Mean & $25 \%$ & $75 \%$ & SD \\
\hline 1 & \multicolumn{2}{|l|}{ Return on total assets } & -0.041 & -0.076 & 0.019 & 0.128 \\
\hline 2 & \multicolumn{2}{|l|}{ Operating margin } & -0.039 & -0.051 & 0.028 & 0.186 \\
\hline 3 & \multicolumn{2}{|l|}{ Assets turnover } & 2.019 & 1.031 & 2.541 & 1.518 \\
\hline 4 & \multicolumn{2}{|l|}{ Return on equity } & -0.088 & -0.349 & 0.339 & 1.822 \\
\hline 5 & \multicolumn{2}{|l|}{ Cash return on assets } & 0.004 & -0.032 & 0.059 & 0.124 \\
\hline 6 & \multicolumn{2}{|l|}{ Return on tangible fixed assets } & -0.117 & -0.129 & 0.230 & 2.026 \\
\hline 7 & \multicolumn{2}{|l|}{ Interest expenses to total debts } & 0.031 & 0.012 & 0.043 & 0.029 \\
\hline 8 & \multicolumn{2}{|c|}{ Non-current assets to total assets } & 0.338 & 0.137 & 0.507 & 0.236 \\
\hline 9 & \multicolumn{2}{|c|}{ Current assets to total assets } & 0.644 & 0.463 & 0.855 & 0.247 \\
\hline 10 & \multicolumn{2}{|c|}{ Tangible non-current assets to total assets } & 0.245 & 0.072 & 0.365 & 0.213 \\
\hline 11 & \multicolumn{2}{|c|}{$\begin{array}{l}\text { Intangible non-current assets to total } \\
\text { assets }\end{array}$} & 0.071 & 0.000 & 0.082 & 0.126 \\
\hline 12 & \multicolumn{2}{|c|}{ Non-current investments to total assets } & 0.015 & 0.000 & 0.008 & 0.056 \\
\hline 13 & \multicolumn{2}{|c|}{ Inventory to total assets } & 0.303 & 0.080 & 0.484 & 0.249 \\
\hline & \multicolumn{2}{|l|}{ Receivables to total assets } & 0.259 & 0.098 & 0.381 & 0.199 \\
\hline & \multicolumn{2}{|l|}{ Cash to total assets } & 0.067 & 0.012 & 0.087 & 0.086 \\
\hline & \multicolumn{2}{|c|}{$\begin{array}{l}\text { Debt to total internal and external } \\
\text { financial funds }\end{array}$} & 1.138 & 1.009 & 1.261 & 0.360 \\
\hline 17 & \multicolumn{2}{|l|}{ Retained benefits to equity } & 1.377 & 0.577 & 1.695 & 3.104 \\
\hline & \multicolumn{2}{|l|}{ Long-term debts to total debt } & 0.225 & 0.029 & 0.367 & 0.222 \\
\hline & Short-term debts to total deb & & 0.775 & 0.633 & 0.970 & 0.222 \\
\hline 20 & Capital to debt & & 0.108 & -0.113 & 0.384 & 0.403 \\
\hline & Cash flow to current debt & & 0.031 & -0.032 & 0.082 & 0.189 \\
\hline & Cash flow to total debt & & 0.017 & -0.025 & 0.059 & 0.124 \\
\hline 23 & Cash flow to current liabilitie & & 0.036 & -0.034 & 0.086 & 0.219 \\
\hline 24 & Current ratio & & 0.935 & 0.579 & 0.979 & 0.887 \\
\hline & Acid test ratio & & 0.473 & 0.171 & 0.574 & 0.775 \\
\hline & Cash ratio & & 0.109 & 0.015 & 0.118 & 0.254 \\
\hline & Debt ratio & & 1.138 & 1.009 & 1.261 & 0.360 \\
\hline & Equity to non-current assets & & -2.102 & -1.566 & -0.032 & 8.172 \\
\hline 29 & Retained benefits to total ass & & -0.207 & -0.306 & -0.041 & 0.324 \\
\hline 30 & Personnel expenses to operat & $g$ income & 0.266 & 0.131 & 0.358 & 0.183 \\
\hline & Depreciation to operating inc & & 0.037 & 0.007 & 0.039 & 0.083 \\
\hline & Financial expenses to operati & income & 0.028 & 0.007 & 0.034 & 0.051 \\
\hline & Operating expenses to operat & ig income & 1.037 & 0.971 & 1.048 & 0.184 \\
\hline & Added value to operating inc & & 0.264 & 0.134 & 0.383 & 0.198 \\
\hline & Depreciation to added value & & 0.118 & 0.025 & 0.159 & 0.288 \\
\hline & Personnel expenses to added & alue & 0.907 & 0.729 & 1.077 & 1.010 \\
\hline & Financial expenses to added & lue & 0.099 & 0.022 & 0.138 & 0.236 \\
\hline 38 & Taxes to added value & & -0.001 & 0.000 & 0.009 & 0.217 \\
\hline & tegorical variables & & & & & \\
\hline & Firm age & $\mathrm{N}$ & $\%$ & & & \\
\hline & $<6$ years & 2,401 & $\begin{array}{c}38.20 \\
\%\end{array}$ & & & \\
\hline & $\geq 6$ years $<20$ years & 3,494 & $\begin{array}{c}55.59 \\
\%\end{array}$ & & & \\
\hline & $\geq 21$ years $<60$ years & 365 & $5.81 \%$ & & & \\
\hline & $\geq 61$ years & 25 & $0.40 \%$ & & & \\
\hline & Firm activity sector & $\mathrm{N}$ & $\mathrm{N}$ & & & \\
\hline & Industry & 1,597 & $\begin{array}{c}25.41 \\
\%\end{array}$ & & & \\
\hline & Construction & 884 & $\begin{array}{c}14.07 \\
\%\end{array}$ & & & \\
\hline & Services & 3,804 & $\begin{array}{c}60.53 \\
\%\end{array}$ & & & \\
\hline
\end{tabular}

\subsection{Regression model}

The results of the multilogit regressions are shown in Table 4. Of all the studied variables, those exerting the most significant influence on the determination of the different adopted outcomes have been selected, following a selection "process of successive steps" (Gallego and Gómez, 2002). Hosmer and Lemeshow tests accept the joint significance of each variable. To measure the good fit of the model, we use Snell and Nagelkerke $\mathrm{R}^{2}$, Akaike (AIC) and Bayes (BIC) criteria of information and cases correctly classified by the model.

A summary of the significant ratios in each case (out-ofcourt/in-court reorganization) is shown in Table 5.

Results reveal that those firms with highest operating mar-
Table 4

Logit model for one year before resolution to business failure

\begin{tabular}{|c|c|c|c|c|c|}
\hline \multicolumn{6}{|c|}{$\begin{array}{l}\text { Reference category: "Liquidation" }(\mathrm{J}=2)(102 \text { companies }) \\
(\mathrm{J}=0) \text { Out-of-court reorganization }(3,130 \text { companies }) \\
(\mathrm{J}=1) \text { In-court reorganization }(3,053 \text { companies })\end{array}$} \\
\hline & \multicolumn{2}{|c|}{$\mathrm{J}=0$} & \multicolumn{3}{|c|}{$\mathrm{J}=1$} \\
\hline & B & Sig. & & B & Sig. \\
\hline $\mathrm{B}_{0}$ & 0.874 & 0.87 & & 33.028 & 0.000 \\
\hline Return on total assets & -0.645 & 0.59 & & 0.371 & 0.483 \\
\hline Operating margin & 14.559 & 0.00 & & 1.970 & 0.000 \\
\hline Cash return on assets & 3.101 & 0.00 & & 1.504 & 0.000 \\
\hline Interest expense to total debt & -2.356 & 0.04 & & 0.312 & 0.559 \\
\hline Current assets to total assets & 12.569 & 0.00 & & -18.591 & 0.000 \\
\hline Tangible non-current assets to total assets & ts 10.478 & 0.02 & & -20.560 & 0.000 \\
\hline $\begin{array}{l}\text { Intangible non-current assets to total } \\
\text { assets }\end{array}$ & 9.095 & 0.06 & & -21.461 & 0.000 \\
\hline Non-current investments to total assets & 5.746 & 0.2 & & -23.943 & 0.000 \\
\hline Receivables to total assets & -1.726 & 0.00 & & -2.135 & 0.000 \\
\hline $\begin{array}{l}\text { Debt to internal and external financial } \\
\text { funds }\end{array}$ & 14.419 & 0.25 & & -89.177 & 0.006 \\
\hline Short-term debts to total debt & -2.152 & 0.0 & & -9.952 & 0.000 \\
\hline Cash-flow to total debt & 3.712 & 0.00 & & 1.676 & 0.000 \\
\hline Debt ratio & -33.988 & 0.00 & & 88.418 & 0.007 \\
\hline Equit & 0.079 & 0.01 & & 0.001 & 0.016 \\
\hline Retained ber & 0.326 & 0.15 & & -0.477 & 0.186 \\
\hline Operating expenses to operating incomes & 14.437 & 0.00 & & 1.882 & 0.000 \\
\hline \multirow[t]{2}{*}{ Firm size } & -0.428 & 0.00 & & -0.320 & 0.000 \\
\hline & BIC & $\begin{array}{c}-2 \log \\
\text { likelihood }\end{array}$ & Sig & $\begin{array}{l}\text { Pseuc } \\
\text { Cox and } \\
\text { Snell }\end{array}$ & $\begin{array}{l}\text { do R2 } \\
\text { Nagelke } \\
\text { rke }\end{array}$ \\
\hline \multirow[t]{3}{*}{ General model } & 3961.401 & 3629.056 & 0.000 & $61.4 \%$ & $78.4 \%$ \\
\hline & sification (o & one year be & fore of & of the outc & come) \\
\hline & $\begin{array}{lr}\text { ourt } & \text { In } \\
\text { ation } & \text { reorg }\end{array}$ & $\begin{array}{l}\text { n-court } \\
\text { ganization }\end{array}$ & Liquid & dation & $\begin{array}{l}\text { Total } \\
\text { success } \\
\text { level }\end{array}$ \\
\hline $98.4 \%$ & & $93.8 \%$ & 6.9 & $9 \%$ & $94.7 \%$ \\
\hline
\end{tabular}

Table 5

Summary of the main obtained results

\begin{tabular}{|c|c|c|}
\hline & Out-of-court reorganization & In-court reorganization \\
\hline+ & $\begin{array}{r}\text { Op } \\
\text { Cash } \\
\text { Cash- } \\
\text { Equity to } \\
\text { Operating exp } \\
\text { Current assets to total assets } \\
\text { Tangible non-current assets to } \\
\text { total assets } \\
\text { Intangible non-current assets to } \\
\text { total assets }\end{array}$ & $\begin{array}{l}\text { cating margin } \\
\text { eturn on assets } \\
\text { ow to total debt } \\
\text { non-current assets } \\
\text { nses to operating income }\end{array}$ \\
\hline- & $\begin{array}{l}\text { Receiva } \\
\text { Short-ter } \\
\text { Interest expense to total debt } \\
\text { Debt ratio }\end{array}$ & $\begin{array}{l}\text { les to total assets } \\
\text { debts to total debt } \\
\text { Firm size } \\
\text { Current assets to total assets } \\
\text { Tangible non-current assets to total assets } \\
\text { Intangible non-current assets to total } \\
\text { assets } \\
\text { Non-current investments to total assets } \\
\text { Debt to internal and external financial } \\
\text { funds }\end{array}$ \\
\hline
\end{tabular}

gins (operating margin, out-of-court reorganization, coefficient $=14.559$, significant at $1 \%$; in-court reorganization, coefficient $=1.970$, significant at $1 \%$ ), a higher contribution of the assets to the generation of resources (cash return on assets, out-of-court reorganization, coefficient $=3.101$, significant at $1 \%$; in-court reorganization, coefficient $=1.504$, significant at $1 \%$ ), a bigger capacity to refund their debts (cash flow to total debt, out-of-court reorganization, coefficient $=3.712$, significant at $1 \%$; in-court reorganization, coefficient $=1.676$, significant at $1 \%$ ) and greater long-term stability (equity to non-current assets, out-of-court reorganization, coefficient $=0.079$, significant at $5 \%$; in-court reorganization, coefficient $=0.001$, significant at $5 \%$ ) have a higher probability of survival by both out-of-court and in-court reorganization. These results are in line with previous studies that posit that greater profitability (Casey et al., 1986; 
Table 3

Descriptive analysis. Panel B. One year before outcome

\begin{tabular}{|c|c|c|c|c|c|c|c|c|c|c|c|c|c|}
\hline \multirow[b]{2}{*}{$*$} & \multicolumn{4}{|c|}{ Out-of-court reorganization } & \multicolumn{4}{|c|}{ In-court reorganization } & \multicolumn{4}{|c|}{ Liquidation } & \multirow{2}{*}{$\begin{array}{c}\text { Mean } \\
\text { differences } \\
\text { test for three } \\
\text { groups }\end{array}$} \\
\hline & Mean & $25 \%$ & $75 \%$ & SD & Mean & $25 \%$ & $75 \%$ & SD & Mean & $25 \%$ & $75 \%$ & SD & \\
\hline 1 & 0.046 & 0.005 & 0.068 & 0.133 & -0.056 & -0.084 & 0.031 & 0.331 & -0.180 & -0.298 & 0.05 & 0.399 & 0.000 \\
\hline 2 & -0.021 & 0.005 & 0.056 & 0.570 & -0.113 & -0.067 & 0.039 & 0.889 & -0.297 & -0.295 & 0.012 & 0.932 & 0.000 \\
\hline 3 & 1.961 & 0.974 & 2.492 & 1.659 & 1.906 & 0.831 & 2.354 & 1.961 & 1.967 & 0.736 & 2.389 & 2.174 & 0.497 \\
\hline 4 & 0.851 & 0.044 & 0.683 & 7.546 & 0.565 & -0.266 & 0.419 & 17.324 & 0.749 & -0.159 & 0.559 & 8.464 & 0.701 \\
\hline 5 & 0.098 & 0.032 & 0.148 & 0.163 & -0.001 & -0.048 & 0.102 & 0.311 & -0.135 & -0.224 & 0.054 & 0.446 & 0.000 \\
\hline 6 & 0.997 & 0.098 & 0.703 & 5.127 & -0.895 & -0.217 & 0.471 & 15.706 & -2.661 & -0.836 & 0.214 & 17.978 & 0.000 \\
\hline 7 & 0.032 & 0.008 & 0.041 & 0.045 & 0.024 & 0.004 & 0.033 & 0.111 & -0.005 & 0.009 & 0.056 & 0.439 & 0.000 \\
\hline 8 & 0.350 & 0.129 & 0.546 & 0.255 & 0.303 & 0.099 & 0.476 & 0.266 & 0.331 & 0.106 & 0.538 & 0.380 & 0.000 \\
\hline 9 & 0.642 & 0.449 & 0.865 & 0.258 & 0.681 & 0.503 & 0.896 & 0.254 & 0.622 & 0.382 & 0.876 & 0.319 & 0.000 \\
\hline 10 & 0.258 & 0.064 & 0.401 & 0.233 & 0.229 & 0.052 & 0.349 & 0.222 & 0.227 & 0.054 & 0.315 & 0.251 & 0.000 \\
\hline 11 & 0.067 & 0.000 & 0.073 & 0.125 & 0.059 & 0.000 & 0.058 & 0.120 & 0.095 & 0.000 & 0.106 & 0.201 & 0.001 \\
\hline 12 & 0.023 & 0.000 & 0.009 & 0.082 & 0.014 & 0.000 & 0.007 & 0.049 & 0.065 & 0.000 & 0.033 & 0.155 & 0.000 \\
\hline 13 & 0.244 & 0.033 & 0.397 & 0.244 & 0.349 & 0.087 & 0.576 & 0.280 & 0.218 & 0.000 & 0.442 & 0.253 & 0.000 \\
\hline 14 & 0.282 & 0.085 & 0.431 & 0.232 & 0.252 & 0.059 & 0.389 & 0.229 & 0.335 & 0.061 & 0.535 & 0.286 & 0.000 \\
\hline 15 & 0.097 & 0.009 & 0.127 & 0.136 & 0.067 & 0.003 & 0.086 & 0.102 & 0.073 & 0.001 & 0.072 & 0.148 & 0.000 \\
\hline 16 & 0.802 & 0.732 & 0.951 & 0.211 & 1.398 & 1.033 & 1.403 & 0.971 & 1.214 & 0.776 & 1.486 & 0.793 & 0.000 \\
\hline 17 & -1.248 & -0.537 & 0.521 & 11.070 & 0.378 & 0.714 & 1.731 & 53.969 & -0.103 & 0.006 & 1.062 & 8.243 & 0.248 \\
\hline 18 & 0.228 & 0.007 & 0.381 & 0.242 & 0.220 & 0.000 & 0.379 & 0.250 & 0.332 & 0.023 & 0.347 & 0.756 & 0.000 \\
\hline 19 & 0.772 & 0.619 & 0.993 & 0.242 & 0.780 & 0.623 & 1.000 & 0.251 & 0.881 & 0.686 & 0.997 & 0.525 & 0.000 \\
\hline 20 & 0.991 & 0.183 & 0.769 & 6.730 & 0.032 & -0.175 & 0.259 & 0.353 & 0.513 & -0.136 & 0.394 & 3.041 & 0.000 \\
\hline 21 & 0.398 & 0.041 & 0.238 & 9.755 & -0.006 & -0.048 & 0.093 & 1.523 & -0.034 & -0.247 & 0.118 & 0.502 & 0.070 \\
\hline 22 & 0.155 & 0.033 & 0.177 & 0.614 & 0.008 & -0.039 & 0.067 & 0.262 & -0.065 & -0.194 & 0.063 & 0.290 & 0.000 \\
\hline 23 & 0.285 & 0.041 & 0.248 & 1.772 & 0.173 & -0.049 & 0.096 & 8.769 & -0.091 & -0.254 & 0.083 & 0.478 & 0.684 \\
\hline 24 & 1.526 & 0.809 & 1.316 & 4.462 & 1.871 & 0.495 & 0.925 & 41.246 & 0.978 & 0.399 & 1.055 & 1.642 & 0.867 \\
\hline 25 & 1.057 & 0.325 & 0.995 & 4.360 & 0.999 & 0.122 & 0.552 & 27.098 & 0.704 & 0.186 & 0.739 & 1.659 & 0.979 \\
\hline 26 & 0.270 & 0.017 & 0.237 & 1.431 & 0.275 & 0.003 & 0.093 & 8.827 & 0.119 & 0.002 & 0.111 & 0.252 & 0.969 \\
\hline 27 & 0.802 & 0.732 & 0.951 & 0.211 & 1.399 & 1.033 & 1.402 & 0.971 & 1.220 & 0.787 & 1.492 & 0.781 & 0.000 \\
\hline 28 & 1.708 & 0.167 & 1.107 & 7.438 & -10.436 & -2.674 & -0.144 & 98.703 & -19.668 & -1.402 & 0.469 & 181.087 & 0.000 \\
\hline 29 & 0.006 & -0.047 & 0.066 & 0.226 & -0.450 & -0.488 & -0.066 & 1.122 & -0.189 & -0.452 & 0.079 & 2.812 & 0.000 \\
\hline 30 & 0.256 & 0.123 & 0.343 & 0.397 & 0.303 & 0.137 & 0.383 & 0.392 & 0.342 & 0.099 & 0.464 & 1.240 & 0.000 \\
\hline 31 & 0.043 & 0.008 & 0.041 & 0.142 & 0.045 & 0.004 & 0.037 & 0.437 & -0.002 & 0.005 & 0.063 & 0.524 & 0.360 \\
\hline 32 & 0.033 & 0.003 & 0.025 & 0.518 & 0.035 & 0.004 & 0.031 & 0.253 & 0.060 & 0.008 & 0.068 & 0.167 & 0.724 \\
\hline 33 & 1.011 & 0.942 & 0.995 & 0.567 & 1.106 & 0.959 & 1.065 & 0.869 & 1.216 & 0.977 & 1.262 & 0.944 & 0.000 \\
\hline 34 & 0.288 & 0.164 & 0.418 & 0.333 & 0.237 & 0.137 & 0.395 & 0.464 & 0.188 & 0.055 & 0.317 & 0.552 & 0.000 \\
\hline 35 & 0.140 & 0.032 & 0.145 & 1.106 & 0.060 & 0.012 & 0.129 & 5.386 & 0.302 & 0.018 & 0.314 & 0.897 & 0.623 \\
\hline 36 & 0.874 & 0.643 & 0.903 & 2.409 & 0.276 & 0.691 & 1.049 & 25.498 & 1.175 & 0.493 & 1.360 & 3.084 & 0.396 \\
\hline 37 & 0.081 & 0.013 & 0.093 & 0.441 & -0.122 & 0.009 & 0.109 & 9.132 & 0.188 & 0.013 & 0.184 & 0.927 & 0.431 \\
\hline 38 & 0.007 & 0.000 & 0.030 & 1.099 & 0.221 & 0.000 & 0.006 & 13.234 & 0.572 & 0.000 & 0.011 & 10.449 & 0.588 \\
\hline
\end{tabular}

See variables denomination and description on panel A Table 3.

Campbell, 1996; Camacho-Miñano et al., 2015), liquidity and solvency (Jacobs et al., 2008) are linked to an increased likelihood of survival, and they extend upon these examples from the literature by detecting the same impact on financially distressed SMEs. On the other hand, the probability of survival is negatively correlated with the weight of the customers and other receivables on the total assets (receivables to total assets, out-of-court reorganization coefficient = -1.726 , significant at $1 \%$; in-court reorganization, coefficient $=-2.135$, significant at $1 \%$ ), the level of short-term indebtedness (short-term debts to total debt, out-of-court reorganization, coefficient $=-2.152$, significant at $1 \%$; in-court reorganization, coefficient $=-9.952$, significant at $1 \%$ ), and the size of the company (firm size, out-of-court reorganization, coefficient $=-0.428$, significant at $1 \%$; in-court reorganization, coefficient $=-0.320$, significant at $1 \%$ ). These results provide evidence that the impact of commercial credit default is the main cause of business failure among SMEs (Holmlund and Kock, 1996). We should also highlight the significance of the financial structure of SMEs. The high weight of shortterm debt that characterizes this type of firms (OECD, 2006;
La Rocca et al., 2010; Keasey et al., 2015) is, according to our results, a hindrance to achieving reorganization under financial distress. This effect is attributed by Keasey et al. (2015) to high transaction costs and the strong information asymmetries of SMEs. Additionally, creditor coordination problems could hinder the achievement of agreements (Routledge and Gadenne, 2000) because creditors with short-term debt might find it difficult to recover their credit, especially when liquidity and solvency are damaged. In fact, short-term lenders and suppliers are the most important credit resources of SMEs financing (Nilsen, 2002), and they are usually unsecured creditors with unfavourable bargaining credit conditions (Keasey et al., 2015). In this sense, as opposed to the case for large firms, the weight of short-term debt in SMEs should be taken into consideration in the evaluation of their survival likelihood. This argument is in line with the results obtained by Altman and Sabato (2007), who show that the credit risk of SMEs should be evaluated by banks with the use of specific scoring and rating systems as they are significantly different from large firms from a financial point of view.

With regard to how internal factors are related to different 
outcomes, the results indicate that for the out-of-court reorganization, firms with a larger weight of the current assets over total assets (current assets to total assets, coefficient $=$ 12.569, significant at $1 \%$ ) and lower guarantee ratios (debt ratio, coefficient $=-33.988$, significant at $1 \%$ ) will have a higher probability of being restructured and continuing than active companies without financial problems by out-of-court reorganization. In contrast, those firms with a lower weight of the current assets over total assets (current assets to total assets, coefficient $=-18.591$, significant at $1 \%$ ) and a larger guarantee ratio (debt ratio, coefficient $=88.418$, significant at $1 \%$ ) have a higher probability of surviving under in-court reorganization. These results provide new evidence about the role of current assets in the economic structure of SMEs towards achieving a sustainable turnaround with an out-of-court reorganization. Although with regard to the impact of fixed assets on overcoming financial distress, evidence has linked that behaviour to a better positioning of the firm to create liquidity and access new credit (Keasey et al., 2015). To our knowledge, no previous study highlights the role of these types of short-term liquidity assets. Because commercial dependency on customers is an important feature of SMEs, some studies have linked greater trade receivables with higher levels of profitability in periods of crisis (Kestens, Van Cauwenberge and Bauwhede, 2012; MartínezSola et al., 2014). In addition, our results confirm that debtors and creditors prefer an out-of-court reorganization process to avoid an in-court, that is, public process, which could damage their image, exacerbating the financial problems of distressed firms.

In the distinctions between the different groups, the levels of tangible (tangible non-current assets to total assets, coefficient $=10.478$, significant at $1 \%$ ) and intangible (intangible non-current assets to total assets, coefficient $=9.095$, significant at $1 \%$ ) assets are also significant as factors that are positively correlated with the possibilities that a company will continue after an out-of-court reorganization. This finding is consistent with previous research that shows fixed assets as being positively related to survival (Keasey et al., 2015) and extends those results to identify the out-of-court reorganization of financially distressed SMEs. In addition, a greater level of intangible assets appears to be positively related to out-of-court reorganization, in line with those researchers positing that these assets lose their value under a liquidation process (De Miguel and Pindado, 2001). According to our results, this finding is also extended to the choice of an outof-court reorganization process, probably because creditors might be afraid of losing the value of these assets under an in-court process. In contrast, the effect of financial expenses on debt (interest expenses to total debt, coefficient $=-2.356$, significant at $1 \%$ ) is negative. This result is consistent with previous literature that posits that disequilibrium of the financial structure deteriorates the solvency of the firm (Keasey et al., 2015) and, consequently, creditors could be reluctant to initiate an out-of-court reorganization procedure due to mistrust regarding the likelihood of recovering their credits when the firm has to support a higher debt cost.

Among those firms suffering a worse financial distress situation, firms with higher levels of tangible (tangible noncurrent assets to total assets, coefficient $=-20.560$, significant at $1 \%$ ), intangible (intangible non-current assets to total assets, coefficient $=-21.461$, significant at $1 \%$ ), non-current assets (non-current investments to total assets, coefficient $=$ -23.943, significant at 1\%), indebtedness (debt to total internal and external financial funds, coefficient $=-89.177$, significant at 1\%) and permanent capital (capital to debt, coeffi- cient $=-8.183$, significant at $1 \%$ ) are more likely to begin a liquidation process than an in-court reorganization process. That is, those firms with a greater disequilibrium in their financial structure and a greater volume of assets are more likely to be liquidated than to start an in-court reorganization process. This finding is consistent with the agency problems that appear when there are limited resources and greater information asymmetries (Gertner and Scharfestein, 1991; Diamond, 1993). Under this scenario, creditors might prefer liquidation to recover a greater value of their credits as soon as possible.

The final outcome of the classification made by this model in the three categories of business failure under consideration confirms the capacity of the accounting information to classify these situations; in fact, it successfully classifies $94.7 \%$ of the cases. Nevertheless, the weight of the various sub-samples used affects the classification, contributing to a greater level of success in the largest sub-samples and reducing the percentages of success in the liquidations to $6.9 \%$. In general terms, our results improve upon those reached by previous studies in terms of classification, such as Poston and Harmon (1994), which were only able to correctly classify $31 \%$ of the total sample.

\subsection{Robustness check}

As a robustness check, we ran the model again, including other variables. As previous literature has recognized, to achieve a successful reorganization, it is necessary that the entrepreneur/manager of an SME has an entrepreneurial mindset and acts with entrepreneurial leadership (Mayr \& Mitter, 2014); that is, in addition to having this mentality ${ }^{3}$, the entrepreneur/manager must be able to transmit it to the rest of the stakeholders, especially to employees. Therefore, it is especially important that SMEs take advantage of their close relationships with various stakeholders to overcome difficult situations through effective communication between entrepreneurs/owners and employees, customers and suppliers. In fact, it is argued that the existence of strong and close relationships between SMEs and their employees, customers and suppliers (Kraus et al., 2013) may enable a quicker reaction to crisis situations and, therefore, can facilitate reorganization. Following this argument, we have included some accounting variables in the model to represent the influence of stakeholders on the firm.

Specifically, we add to our analyses some variables to represent stakeholders' influence on the firm: (1) suppliers' influence (cost of goods sold over operating incomes), (2) employees' influence (salaries and other personnel expenses over operating incomes); (3) customer influence (uncollectable customer debt over operating income); (4) financial creditors' influence (financial expenses over total debt); (5) stockholders' influence (own funds over total debt). Some of these variables are not significant in the model (see Table 6).

The results remain largely similar (significant variables in the main model in black and italics), so to the extent that our results are not qualitatively different in the significance and sign of the variables, we are reasonably assured that our results are robust.

\footnotetext{
${ }^{3}$ The entrepreneurs (and, therefore, those with an entrepreneurial mindset) are identified by five fundamental aspects (McGrath \& MacMillan, 2000, p. 2-3): 1) they passionately seek new opportunities; 2) they pursue opportunities with enormous discipline; 3 ) they pursue only the very best opportunities and avoid exhausting themselves and their organizations by chasing after every option; 4) they focus on adaptive execution; and, 5) they involve many people - both inside and outside the organization - in their pursuit of an opportunity.
} 
Table 6

Logit model for one year before resolution to business failure

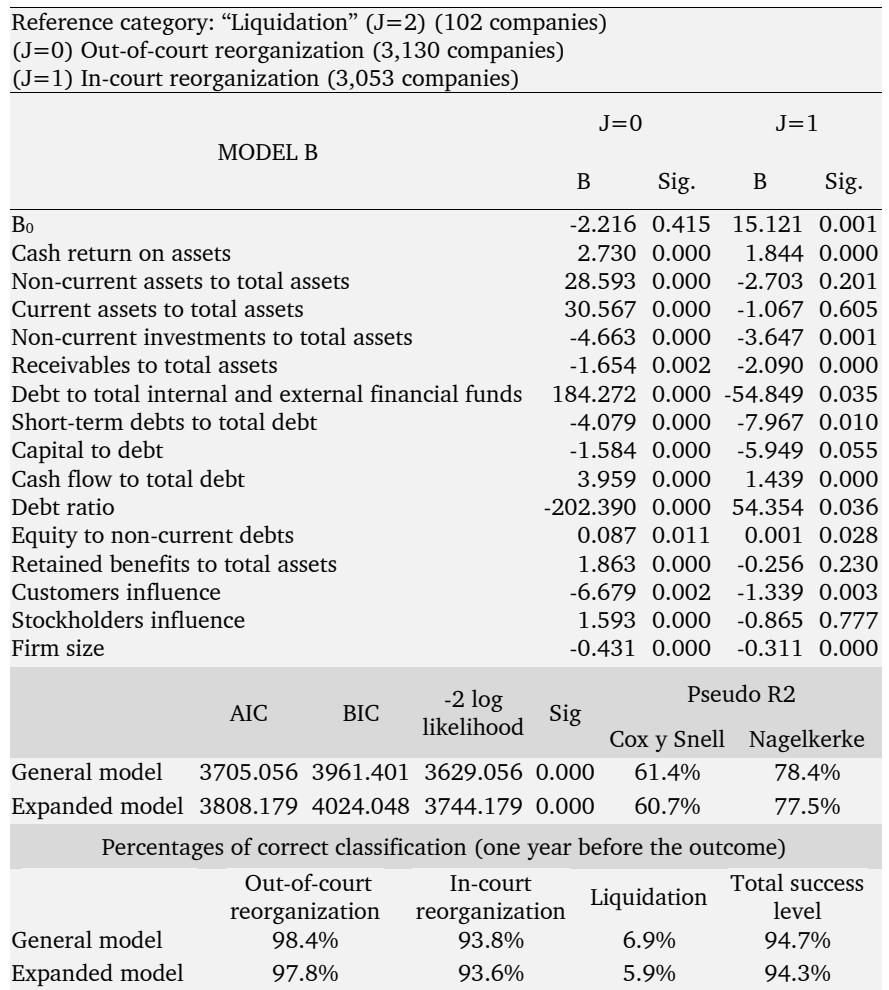

\section{Discussion and conclusion}

The main aim of our study was to examine the factors that influence the probability that financially distressed SMEs will be able to overcome difficult economic and financial situations and survive by means of out-of-court or in-court or legal reorganization. The present study contributes to theory building by examining how heterogeneity among SMEs regarding the management of critical resources influences their ability to survive under difficult situations. In fact, our results highlight the intrinsic heterogeneity among SMEs in financial distress and provide explanations for the internal factors influencing the firm's ability to overcome this situation and survive. A further goal is to compare the characteristics of firms that, when in financial distress, survive under an outof-court reorganization with those firms that follow in-court reorganization. Although advantages have been attributed to an out-of-court process against a legal or in-court reorganization, our results give some insights into understanding why firms have chosen in-court reorganization.

SMEs usually face resource constraints (Jarillo, 1989), and their resources should be used carefully because erroneous decisions have a greater and more negative impact on their future than in the case of large businesses (Amelingmeyer \& Amelingmeyer, 2005). However, SMEs are usually able to adapt quickly to changes in the environment because their structures are simpler (Altman \& Sabato, 2007), thus facilitating managerial restructuring (Astebro \& Winter, 2002) and overcoming difficult situations. In this sense, firms that adapt better to new circumstances when they are in default or financial distress are also able to overcome the situation and survive in the future. The success and pursuit of business strategies depend mainly on the availability of resources (March \& Simon, 1958; Ullmann, 1985). Our results provide additional understanding about how management of critical resource heterogeneity among SMEs influences the financial distress outcome.

Specifically, in relation to our first research question, our findings suggest that the different combinations of internal resources influence the likelihood of SME survival. First, our analysis indicates that when management is able to create value in an efficient way from the firm assets, it presents better conditions under which to overcome difficult situations; therefore, there is a higher probability of survival (Espina, 1994; Campbell, 1996; Kim \& Kim, 1999; Van Hemmen, 2000). This effect is driven mainly by efficient management of the operating cycle (operating margin and cash return on assets). As proposed by resource-based theory, internal resources and capabilities are essential for survival in competitive environments (Barney, 1991), for example, by achieving competitive advantages due to the efficient use of resources (Sirmon \& Hitt, 2003; Sirmon, Hitt, \& Ireland, 2007), as posited by the "asset orchestration" logic (Sirmon \& Hitt, 2003; Helfat et al., 2007). Furthermore, firms can fail in the same way even if they operate in an unchanging environment (Lukason \& Hoffman, 2014). Our results confirm that SMEs' economic and financial structures differ from those of large firms and that these differences are significant when judging the ability of distressed firms to overcome difficulties. Specifically, short-term debt and assets appear to be significant in evaluating the likelihood that SMEs will overcome financial distress, whereas in studies of large firms, long-term debt and fixed assets are the most significant. It would therefore seem that the short-term outlook is more relevant in SME risk evaluation.

Second, our results also confirm that SMEs that face higher levels of account receivables are more likely to suffer liquidation and to disappear. An explanation for this result is provided by credit rationing theory inherent to the information asymmetries usually linked to relations between SMEs and creditors (Stiglitz \& Weiss, 1981; Lapar \& Graham, 1988; Baas \& Schrooten, 2006; Fatoki \& Odeyemi, 2010). From this point of view, banks and other financial institutions may be reluctant to offer long-term debt or may require higher interest rates to compensate for the increased risk (Berger \& Udell, 1998) due to the information asymmetries linked to a lack of transparency in SMEs' accounting information. Thus, it would appear that SMEs have a high dependency on commercial credit (Wilson \& Gorb, 1983; Holmlund \& Kock, 1996) because they try to relieve financial pressure through short-term debt, especially during periods of financial insolvency (Keasey et al., 2015). In this context, if payment from customers is delayed, the company will face significant liquidity problems (Walker \& Petty, 1978). These liquidity problems will make it difficult for the company to face the payment of its own debts, thereby increasing the risk level of the firm. Thus, organizations that fail to manage accounting receivables and retain more funds as credit to customers reduce their performance (Poutziouris, Chittenden, \& Michaelas, 1998), thereby endangering their survival. In addition, a higher ratio of short-term debt to total debt exacerbates liquidity problems (Grablowsky, 1984; Pike \& Pass, 1987). The result that a greater level of short-term debt is mainly related to liquidation supports this explanation. Therefore, the efficient management and design of financial practices are essential if SMEs respond well to financial difficulties (Jarvis, Kitching, Curran, \& Lightfoot, 1996; Peel \& Wilson, 1996).

Third, our analysis also indicates that slack (equity to non-current assets) increases the likelihood of reorganization. The guarantee coefficient (equity to non-current assets) 
has a positive effect on the probability of survival. Accordingly, our findings reveal that financial slack, manifested as a greater level of equity (Brealey \& Myers, 1996) increases the likelihood of survival under reorganization. This finding reinforces the idea of slack reducing risk and helping the firm to survive (Hambrick \& DÀveni, 1988; Reuer \& Leiblein, 2000). In fact, slack could become a facilitator of a strategic adaptation to a turbulent environment because SMEs could use it to introduce new products and enter new markets (Thompson, 1967).

Finally, company size appears to be negatively correlated with the probability of restructuring. Regarding this variable, previous models of the prediction of the business failure outcome have obtained contradictory conclusions. Authors such as White (1983) find a positive correlation between company size and the probabilities of managerial restructuring. He attributes this correlation to the existence of free assets to enable the contracting of new debts and financing to face the restructuring process. On the other hand, Campbell (1996) and Kim and Kim (1999) state that this finding is probably due to the greater social and political pressure exerted by these types of companies and to the greater relative importance that they represent for their creditors. In this vein, Bryan et al. (2002) underline two indicative reasons for this relationship: a) big companies often have difficulties in liquidating assets, which would favour managerial restructuring, and b) governments pay more attention to larger companies due to their economic and social weight. On the other hand, Dunne and Hughes (1994) and Hart and Oulton (1996) state that company size is negatively correlated with managerial success, which can be extended to managerial restructuring probabilities.

Regarding the second research question, our findings corroborate that different internal resources influence the choice between out-of-court reorganization and in-court reorganization. Specifically, our results reveal that while possessing higher levels of assets increases the likelihood of survival, when starting an out-of-court reorganization, greater debt increases the likelihood of liquidation. In contrast, in the choice of in-court reorganization, a greater level of assets increases the likelihood of liquidation, and a greater level of debt reduces it. These apparently confusing results provide an opportunity for empirical testing of the discussion in the previous literature on the role of assets as a guarantee for debts and show how different debtors contribute to the survival or liquidation of the firm. Agency problems arise from creditors with claims on failed firms as a consequence of limited resources and greater information asymmetries (Gertner \& Scharfestein, 1991; Diamond, 1993). In general terms, the level of assets on the balance sheet is important for obtaining new financing with which to face the financial problems that could exist or to develop the restructuring processes (Keasey et al., 2015), due to them usually serving as a guarantee for debtors' repayment (White, 1983; Casey et al., 1986; Campbell, 1996). However, due to the characteristics of the out-ofcourt reorganization process and the likelihood of holdout problems arising, greater debt favours liquidation. Under informal processes of reorganization, creditors could require new securities and greater interest rates (interest expenses to total debt), slowing down or inhibiting the reorganization. Alternatively, in-court resolution will allow creditors to control other opportunistic behaviours of management or debtors, as greater leverage influences the perception of the creditors regarding their ability to recover the credit, they find greater safety within a legal procedure (Chatterjee et al., 1996). Particularly, as financial institutions are usually the main creditors to SMEs and because they generally enjoy priority in the recovery of credit in in-court reorganization processes, these institutions prefer this procedure to an out-of-court process (Gestner and Scharfestein, 1991; Diamond, 1993; Asquith et al., 1994). Moreover, creditors can force the liquidation of the company if it has enough assets at its disposal to face such difficulties and they perceive that a reorganization process could culminate in the transfer of resources to other claimants (Gestner \& Scharfestein, 1991; Diamond, 1993). Indeed, we have found evidence consistent with this assertion. According to the issues discussed, the right question to ask is not whether one type of reorganization or another is good or bad for the outcome of the firm but rather what firm resources and capabilities enable its reorganization either out-of-court or in-court.

Our results have important practical implications for managers and policy makers, especially those interested in SME survival under difficult situations. First, attention needs to be focused on the ability to create value, receivable and working capital financial design and historical slack. Thus, policy makers should take into account that the firm's ability to overcome difficult situations depends on internal resources and requires special attention to prevent SMEs' bankruptcy. Our study also emphasizes that internal resources also condition the type of reorganization (out-of-court versus in-court). Thus, our study highlights the importance of creditors and their perception of repayments within the choice of process.

Notwithstanding this paper's contributions, it is not without limitations. Because our sample is based on failed firms, information about external factors that contribute to overcoming difficult situations is difficult to achieve. Further research is needed about how complementary or substitutive effects among internal and external factors might contribute to explain failure outcomes in SMEs, taking as a reference the postulates of the asset orchestration perspective. In addition, further analysis with different variables representing the stakeholders' impact on the firm could add a new perspective to evaluate the role of internal or external stakeholders in the business failure process.

\section{Funding}

This research did not receive any specific grant from funding agencies in the public, commercial or not-for-profit sectors.

\section{Conflict of interests}

The author declare no conflict of interests.

\section{References}

Abad, C., Arquero, J.L., \& Jiménez, S. (2003). Proceso de Fracaso Empresarial. Identificación y Contrastación Empírica. Paper presented to XIII AECA Congress. Cádiz.

Aldrich, H. E., \& Auster, E. (1986). "Even Dwarfs Started Small: Liabilities of Age and Size and Their Strategic Implications," in Staw, B.M and Cummings, L.L (Eds), Research in Organizational Behavior, 8, 165-198.

Alemany, J., \& Monllau, J. (1997). Disponibilidad y defectos en la presentación de las cuentas anuales en el registro mercantil. Técnica Contable, 581, 381-393.

Allen, K. (1995). Launching New Ventures-An Entrepreneur- 
ial Approach. Chicago: Upstart Publishing Company.

Altman, E.I. (1983). Corporate Financial Distress: A Complete Guide to Predicting, Avoiding, and Dealing with Bankruptcy. New York: John Wiley \& Sons.

Altman, E.I, \& Hotchkiss, E. (2006). Corporate Financial Distress and Bankruptcy: Predict and avoid bankruptcy, analyse and invest in distresses debt. New York: John Wiley \& Sons.

Altman, E. I., \& Sabato, G. (2007). Modelling credit risk for SMEs: Evidence from the US market. Abacus, 43(3), 332357. https://doi.org/10.1111/j.1467-6281.2007.00234.x

Almunia, M., López-Rodríguez, D., \& Moral-Benito, E. (2018). Evaluating the macro. Representativeness of a firm-level database: an application for the Spanish economy. Banco de España Occasional Paper No. 1802.

Amat, O.; Gowthorpe, C., \& Perramon, J. (2004). Fiabilidad de la información contable. El caso de las empresas cotizadas. XI Encuentro de Profesores Universitarios de Contabilidad. Granada (Spain).

Amelingmeyer, J., \& Amelingmeyer, G. (2005). "Wissensmanagement beim Führungswechsel in KMU" in Meyer, J.A. (Ed) Wissens- und Informationsmanagement in kleinen und mittleren Unternehmen, Josef Eul Verlag, Lohmar, Cologne, pp. 479-488.

Amit, R., \& Schoemaker, P. J. (1993). Strategic assets and organizational rent. Strategic Management Journal, 14(1), 33-46. https://doi.org/10.1002/smj.4250140105.

Argenti, J. (1976). Corporate Collapse-The Causes and Symptoms. New York: Halstead Press, a Division of John Wiley and Sons, Inc.

Asquith, P., Gertner, R., \& Scharfstein, D. (1994). Anatomy of Financial Distress: An Examination of Junk-Bond Issuers. Quarterly Journal of Economics, 109(3), 625-658. https:// doi.org/10.2307/2118416

Astebro, T., \& Winter, J. (2002). More than Dummy: The Probability of Failure, Survival and Acquisition of Firms in financial Distress. Working Papers. University of Totonto Rotman School of Management, 1-42.

Audretsch, D.B., \& Mahmood, T. (1994). The rate of hazard confronting new firms and plants in U.S. manufacturing. Review of Industrial Organization, 9(1), 41-56. https: //doi.org/10.1007/BF01024218

Baas, T., \& Schrooten, M. (2006). Relationship banking and SMEs: A theoretical analysis. Small Business Economics, 27(2-3), 127-137. https://doi.org/10.2139/ssrn.788344

Barney, J.B. (1991). Firm Resources and Sustained Competitive Advantage. Journal of Management, 17(1), 99-120. https://doi.org/10.1177/014920639101700108

Barniv, R., Agarwal, A., \& Leach, R. (2002). Predicting Bankruptcy Resolution. Journal of Business Finance and Accounting, 29 (3-4), 497-520. https://doi.org/10.1111/ 1468-5957.00440

Beck, T., Demirgüç-Kunt, A., \& Maksimovic, V. (2008). Financing patterns around the world: Are small firms different? Journal of Financial Economics, 89(3), 467-487. https: //doi.org/10.1016/j.jfineco.2007.10.005

Berger, A.N., \& Udell, G.F. (1998). The Economics of Small Business Finance: The Roles of Private Equity and Debt Markets in the Financial Growth Cycle. Board of Governors of the Federal Reserve System (U.S.). Finance and Economics Discussion Series.

Berryman, J. (1983). Small business failure and survey of the literature. European Small Business Journal, 1(4), 47-59. https://doi.org/10.1177\%2F026465608300100404

Betker, B.L. (1997). The administrative costs of debt restructurings: some recent evidence. Financial Management,

\section{6(4), 56-68. https://doi.org/10.2307/3666127}

Bisogno, M., \& De Luca, R. (2015). Financial distress and earnings manipulation: Evidence from Italian SMEs. Journal of Accounting and Finance, 4(1), 42-51.

Blazy, R., Martel, J., \& Nigam, N. (2014). The choice between informal and formal restructuring: The case of French banks facing distressed SMEs. Journal of Banking \& Finance, 44, 248-263. https://doi.org/10.1016/j.jbankfin. 2014.04.015

Box, M. (2008). The Death of Firms: Exploring the Effects of Environment and Birth Cohort on Firm Survival in Sweden. Small Business Economics, 31(4), 379-393. https://doi.org/ 10.1007/s11187-007-9061-2

Boyle, R.D., \& Desai, H. B. (1991). Turnaround strategies for small firms. Journal of Small Business Management, 29(3), 33-42.

Brealey, R. A., \& Myers, S. C. (1996). Principles of financial management. New York: Mc Graw-Hill.

Bryan, M., Tiras, L., \& Wheatley, M. (2002). The Interaction of Solvency with Liquidity and its Association with Bankruptcy Emergence. Journal of Business, Finance \& Accounting, 29(7-8), 935-965. https://doi.org/10.1111/1468-5957. 00456

Camacho-Miñano, M.M., Segovia-Vargas, M.J., \& PascualEzama, D. (2015). Which Characteristics Predict the Survival of Insolvent Firms? An SME Reorganization Prediction Model. Journal of Small Business Management, 53(2), 340354. http://doi.org/10.1111/jsbm.12076

Campbell, S.V. (1996). Predicting Bankruptcy Reorganization for Closely Held Firms. Accounting Horizons, 10(3), 1226.

Campillo, J. P., Serer, G. L., \& Ferrer, E. V. (2013). Validez de la información financiera en los procesos de insolvencia. Un estudio de la pequeña empresa española. Cuadernos de Economía y Dirección de la Empresa, 16(1), 29-40. https:// doi.org/10.1016/j.cede.2012.05.001

Carlsson, B. (1999). Small business, entrepreneurship, and industrial dynamics. In Are Small Firms Important? Their Role and Impact (pp. 99-110). Springer, Boston, MA.

Carmeli, A., \& Schaubroeck, J. (2008). Organisational Crisis-Preparedness: The Importance of Learning from Failures. Long Range Planning, 41(2), 177-196. http://doi.org/ 10.1016/j.lrp.2008.01.001

Carter, R., \& Van Auken, H. (2006). Small Firm Bankruptcy. Journal of Small Business Management, 44(4), 493512. https://doi.org/10.1111/j.1540-627X.2006.00187.x

Casey, C., McGee, V., \& Sticney, C. (1986). Discriminating Between Reorganized and Liquidated Firms in Bankruptcy. The Accounting Review, 61(2), 249-262. https://www.jstor. org/stable/247256

Chatterjee, S., Dhillon, U., \& Ramírez, G. (1996). Resolution of Financial Distress: Debt Restructurings via Chapter 11, Prepackaged Bankruptcies, and Workouts. Financial Management, 25, 5-19. https://doi.org/10.2307/3665899

Chen, N. (2003). Asymmetric information, the choice of financial distress resolution. Working paper, Columbia University.

Claessens, S. \& Klapper, L. (2005). Bankruptcy around the World: Explanations of its relative use. American Law and Economics Review, 7(1), 253-283. https://doi.org/10.1093/ aler/ahi004

Couwenberg, O., \& De Jong, A. (2008). Costs and recovery rates in the Dutch liquidation-based bankruptcy system. European Journal of Law and Economics, 26(2), 105127. https://doi.org/10.1007/s10657-008-9058-6

Cultrera, L., \& Brédart, X. (2016). Bankruptcy pre- 
diction: the case of Belgian SMEs. Review of Accounting and Finance, 15(1), 101-119. https://doi.org/10.1108/ RAF-06-2014-0059

Cyert, R.M., \& March, J.G. (1963). A Behavioral Theory of the Firm. Englewood Cliffs, N.J.: Prentice-Hall.

Day, J. (2000). Commentary-the value and importance of the small firm to the world economy. European Journal of Marketing, 34(9/10), 1033-1037. http://doi.org/10.1108/ 03090560010342764

De Miguel, A., \& Pindado, J. (2001). Determinants of capital structure: new evidence from Spanish panel data. Journal of corporate finance, 7(1), 77-99. https://doi.org/ 10.1016/S0929-1199(00)00020-1

Dewaelheyns, N., \& Van Hulle, C. (2008). Legal reform and aggregate small and micro business bankruptcy rates: evidence from the 1997 Belgian bankruptcy code. Small Business Economics, 31(4), 409-424. https://doi.org/10.2139/ ssrn.905196

Diamond, D. (1993). Seniority and the Maturity of Debt Contracts. Journal of Financial Economics, 33, 341-368. https://doi.org/10.1016/0304-405X(93)90011-Y

Dunne, P., \& Hughes, A. (1994). Age, Size, Grown and Survival: UK Companies in the 1980t's. Journal of Industrial Economics, 42(2), 40-115. https://doi.org/10.2307/2950485

Easterbrook, F. (1990). Is corporate bankruptcy efficient? Journal of Financial Economics, 27(2), 411-417. https://doi. org/10.1016/0304-405X(90)90062-5

Espina, A. (1994). La Crisis del Sistema Concursal Español. ICE, Tribuna de Economía, 727, 7-32.

European Commission (2014). Partial and Fragile Recovery. Annual Report on European SMEs 2013/2014, Available online at: http://ec.europa.eu/enterprise/policies/ sme/facts-figures-analysis/performance-review/files/ supporting-documents/2014/annual-report-smes-2014_en. pdf

European Commission (2016). Annual Report on European SMEs 2015/2016. Available at: https://ec.europa.eu/jrc/sites/jrcsh/files/annual/ report/ / eu/ smes/2015-16.pdf.

Fatoki, O., \& Odeyemi, A. (2010). Which new small and medium enterprises in South Africa have access to bank credit? International Journal of Business and Management, 5(10), 128. https://doi.org/10.5539/ijbm.v5n10p128

Filipe, S. F., Grammatikos, T., \& Michala, D. (2016). Forecasting distress in European SME portfolios. Journal of Banking \& Finance, 64, 112-135. https://doi.org/10.1016/ j.jbankfin.2015.12.007

Fisher, T., \& Martel, J. (1995). The Creditors' financial reorganization decision: new evidence from Canadian data. Journal of Law, Economics and Organization, 11(1), 113-126. https://doi.org/10.1093/oxfordjournals.jleo.a036862

Fitzpatrick, P.J. (1924). Transitional Stages of a Business Failure. The Accounting Review, 9(4), 337-340.

Flagg, J.C., Giroux, G.A., \& Casper, E. (1991). Predicting corporate Bankruptcy Using Failing Firms. Review of Financial Economics, 1(1), 67-79. https://doi.org/10.5539/ijbm. v6n3p208

François, P., \& Raviv, A. (2017). Heterogeneous beliefs and the choice between private restructuring and formal bankruptcy. The North American Journal of Economics and Finance, 41, 156-167. https://doi.org/10.1016/j.najef.2017.04.006

Franks, J., \& Torous, W. (1989). An empirical investigation of US firms in reorganization. Journal of Finance, 44 (3), 747769. https://doi.org/10.1111/j.1540-6261.1989.tb04389.x

Freear, J., Sohl, J.E., \& Wetzel, W.E. (1995). Who Bankrolls Software Entrepreneurs? In Bygrave, W.D., Bird, B.J., Birley,
S., Churchill, N.C., Hay, M., Keeley, R.H. and Wetzel, W.E.Jr. (Eds.), Frontiers of Entrepreneurship Research 1995, Wellesley, MA, Babson College, pp. 394-406.

Fraser, S., Storey, D., Frankish, J., \& Roberts, R. (2002). The Relationship Between Training and Small Business Performance: an Analysis of the Barclays Bank Small Firms Training Loan Scheme. Environment and Planning C: Government and Policy, 20(2), 211-233. https://doi.org/10.1068\% 2Fc0111

Gallego, A., \& Gómez, A. (2002). Análisis integrado de la Absorción y Quiebra Empresarial Mediante la Estimación de un Modelo Multilogit. Spanish Journal of Finance and Accounting/Revista Española de Financiación y Contabilidad, 31(111), 111-144. https://doi.org/10.1080/ 02102412.2002.10779446

García, J. M., Osma, B. G., \& Neophytou, E. (2009). Earnings quality in expost failed firms. Accounting and Business Research, 39(2), 119-138. http://doi.org/10.1080/00014788. 2009.9663353

García-Pérez-de-Lema, D., Alfaro-Cortes, E., ManzanequeLizano, M., \& Banegas-Ochovo, R. (2012). Strategy, competitive factors and performance in small and medium enterprise (SMEs). African Journal of Business Management, 6(26), 7714-7726. https://doi.org/10.5897/AJBM11.1746

García-Posada, M., \& Mora-Sanguinetti, J.S. (2013). Are there alternatives to Bankruptcy? A study of small business distress in Spain. Banco de España: Working Paper No. 1315.

Garrido, J. M. (2012). Out-of-court debt restructuring. Washington: Word Bank.

Gaskill, L. R., Van Auken, H. E., \& Manning, R. A. (1993). A factor analytic study of the perceived causes of small business failure. Journal of small business management, 31(4), 18-18.

Geroski, P. A., Mata, J., \& Portugal, P. (2010). Founding conditions and the survival of new firms. Strategic Management Journal, 31 (5), 510-529. https://doi.org/10.1002/smj. 823

Gertner, R., \& Scharfestein, D. (1991). A Theory of Workouts and the Effects of Reorganization Law. Journal of Finance, 46, 1189-1222. https://doi.org/10.1111/j. 1540-6261.1991.tb04615.x

Gilson, S., John, K., \& Lang, L. (1990). Troubled Debt Restructurings. An Empirical Study of Private Reorganization of Firms in Default. Journal of Financial Economics, 27(2), 315-353. https://doi.org/10.1016/0304-405X(90)90059-9

Gómez, M. E., de la Torre, J. M., \& Román, I. (2008). Análisis de sensibilidad temporal en los modelos de predicción de insolvencia: una aplicación a las PYMES industriales. Spanish Journal of Finance and Accounting, 37(137), 85-111. https://doi.org/10.1080/02102412.2008.10779640

Grablowsky, B.J. (1984). Financial management of inventory. Journal of Small Business Management, 22(3), 59-65.

Hambrick, D.C., \& D'Aveni, R. A. (1988). Large corporate failures as downward spirals. Administrative science quarterly, 1-23. https://doi.org/10.2307/2392853

Hart, P., \& Oulton, N. (1996). Growth and Size of Firms. The Economic Journal, 106(438), 1.242-1252. https://doi. org/10.2307/2235518

Helfat, C.E., Finkelstein, S., Mitchell,W., Peteraf, M., Singh, H., Teece, D., \& Winter, S.G. (2007). Dynamic capabilities: Understanding strategic change in organizations. Malden, MA: Blackwell.

Hill, J., \& Wright, L. (2001). A qualitative research agenda for small to medium-sized enterprises. Marketing intelligence \& planning, 19(6), 432-443. https://doi.org/10.1108/ EUM0000000006111

Hodgetts, R. M., \& Kuratko, D.F. (1995). Effective Small 
Business Management. New York: The Dryden Press.

Holmlund, M., \& Kock, S. (1996). Buyer dominated relationships in a supply chain-a case study of four small-sized suppliers. International Small Business Journal, 15(1), 26-40. https://doi.org/10.1177/0266242696151002

Informa (2017). Evolución de los procesos concursales en España. Retrieved 2019 June 27 from https://cdn.informa.es/sites/5809ccf0cdaeee62837a6c07/ content/ entry5809cd5ecdaeee62837a6c51/

591e8f8111911f00b0ef659f/files/HistoricoConcursos/ 2017.pdf?1495175041

Jacob, R., Julien, P.A., \& Raymond, L. (1997). Developing the network enterprise: foundations, technologies and experiences. Proceedings of the 7th International Forum on Technology Management, Kyoto, (November 3-7), 178-183.

Jacobs, M., Karagozoglu, A. K., \& Layish, D. N. (2008). Understanding and predicting the resolution of financial distress. Paper presented to Risk Management Conference. Florence.

Jacobs, M., Karagozoglu, A. K., \& Layish, D. N. (2012). Resolution of corporate financial distress: an empirical analysis of processes and outcomes. Journal of portfolio Management, 38(2), 117. https://doi.org/10.3905/jpm.2012.38.2. 117

Jarillo, J. C. (1989). Entrepreneurship and growth: The strategic use of external resources. Journal of Business Venturing, 4(2), 133-147. https://doi.org/10.1016/ 0883-9026(89)90027-X

Jarvis, R., Kitching, J., Curran, J., \& Lightfoot, G. (1996). The financial management of small firms: an alternative perspective. ACCA Research Report, 49, Certified Accountants Education Trust: London.

Jensen, M. (1989). Active Investors, LOBs, and the Privatization of Bankruptcy. Journal of Applied Corporate Finance, 22(1), 35-44. https://doi.org/10.2139/ssrn.244152

Jones, S., \& Hensher, D.A. (2007). Modelling Corporate Failure: A Multidimensional Nested Logit Analysis for Unordered Outcomes. The British Accounting Review, 39, 89107. https://doi.org/10.1016/j.bar.2006.12.003

Jostarndt, P., \& Sautner, Z. (2010). Out-of-court restructuring versus formal bankruptcy in a non-interventionist bankruptcy setting. Review of Finance, 14(4), 623-668. https: //doi.org/10.1093/rof/rfp022

Keasey, K., Pindado, J., \& Rodrigues, L. (2015). The determinants of the costs of financial distress in SMEs. International Small Business Journal, 33(8), 862-881. https: //doi.org/10.1177/0266242614529317

Kestens, K., Van Cauwenberge, P., \& Bauwhede, H. V. (2012). Trade credit and com- pany performance during the 2008 financial crisis. Accounting \& Finance, 52(4), 11251151. https://doi.org/10.1111/j.1467-629X.2011.00452.X

Kharbanda, O. P., \& Stallworthy, E.A. (1985). Corporate Failure: Prediction, Panacea and Prevention. London: McGraw-Hill Book Company (UK) Limited.

Kim, M., \& Kim, M. (1999). A Note on the Determinants of the Outcomes of Bankruptcy Petitions: Evidence from Korea. Journal of Business Finance \& Accounting, 26(7-8), 997-1011. https://doi.org/10.1111/1468-5957.00283

Kraaijenbrink, J., Spender, J. C., \& Groen, A. J. (2010). The resource-based view: a review and assessment of its critiques. Journal of management, 36(1), 349-372. https: //doi.org/10.1177/0149206309350775

Kraemer-Eis, H., Lang, F., \& Gvetadze, S. (2015). "SME finance in Europe", in Kolev, A. and Tanayama, T. (Eds.), Investment and Investment Finance in Europe 2013, European
Investment Bank, pp. 97-130.

Kraus, S., Moog, P., Schlepphorst, S., \& Raich, M. (2013). Crisis and Turnaround Management in SMEs: A QualitativeEmpirical Investigation of 30 Companies. International Journal of Entrepreneurial Venturing, 5(4), 406-430. https: //doi.org/10.1504/IJEV.2013.058169

Kuratko, D.F., Goodale, J.C., \& Hornsby, J. S. (2001). Quality practices for a competitive advantage in smaller firms. Journal of Small Business Management, 39(4), 293311. https://doi.org/10.1111/0447-2778.00027

La Rocca, M., La Rocca, T., \& Cariola, A. (2010). The influence of local institutional differences on the capital structure of SMEs: Evidence from Italy. International small business journal, 28(3), 234-257. https://doi.org/10.1177/ 0266242609360614

Labatut, G., Pozuelo, J., \& Veres, E. J. (2009). Modelización temporal de los ratios contables en la detección del fracaso empresarial de la PYME española. Spanish Journal of Finance and Accounting/Revista Española de Financiación y Contabilidad, 38(143), 423-447. https://doi.org/10.1080/ 02102412.2009 .10779672

Laitinen, E. (1991). Financial Ratios and Different Failure Processes. Journal of Business Finance and Accounting, 18, 649-673. https://doi.org/10.1111/j.1468-5957.1991. tb00231.x

Laitinen, E. K., \& Gin Chong, H. (1999). Early-warning system for crisis in SMEs: preliminary evidence from Finland and the UK. Journal of Small Business and Enterprise Development, 6(1), 89-102. https://doi.org/10.1108/ EUM0000000006665

Laitinen, E. K., Lukason, O., \& Suvas, A. (2014). Are firm failure processes different? Evidence from seven countries. Investment Management and Financial Innovations, 11(4), 212-222.

Lapar, L.A., \& Graham, D. H. (1988). Credit rationing under a deregulated financial system. Working Paper Serie No. 88-19.

Lizarraga, F. (1997). Utilidad de la información contable en el proceso de fracaso: análisis del sector industrial de la mediana empresa española. Revista Española de Financiación y Contabilidad, 26 (93), 871-915.

Ló, A.W. (1986). Logit versus discriminant analysis. A specification test and application to corporate bakrupticies. Journal of Econometric, 31, 151-178. https://doi.org/10. 1016/0304-4076(86)90046-1

López, J., Gandía, J.L., \& Molina, R. (1998). La Suspensión de Pagos en las Pymes: Una Aproximación Empírica. Revista Española de Financiación y Contabilidad, 94, 71-97.

Lopucki, L.M. (1983). The Debtor in Full Control-Systems Failure under Chapter 11 of the Bankruptcy Code? American Bankruptcy Law Journal, 57, 99-126.

Lukason, O., \& Hoffman, R. C. (2014). Firm bankruptcy probability and causes: An integrated study. International Journal of Business and Management, 9(11), 80-91. https: //doi.org/10.5539/ijbm.v9n11p80

Lukason, O., Laitinen, E. K., \& Suvas, A. (2016). Failure processes of young manufacturing micro firms in Europe. Management Decision, 54(8), 1966-1985. https://doi.org/ 10.1108/MD-07-2015-0294

Madrid-Guijarro, A., García-Pérez-de-Lema, D., \& Van Auken, H. (2011). An analysis of non-financial factors associated with financial distress. Entrepreneurship and Regional Development, 23(3-4), 159-186. https://doi.org/10.1080/ 08985620903233911

March, J.G., \& Simon, H.A. (1958). Organizations. Oxford, 
England: Wiley.

Martínez-Sola, C., García-Teruel, P. J., \& Martínez-Solano, P. (2014). Trade credit and SME profitability. Small Business Economics, 42(3), 561-577. https://doi.org/10.1007/ s11187-013-9491-y

Mayr, S. (2015). Reorganization in SMEs: DecisionMaking Processes and Conflicts of Interest among Stakeholders. European Journal of Management, 15(2), 45-56. https: //doi.org/10.18374/EJM-15-2.3

Mayr, S., \& Mitter, C. (2014). Rising like a phoenix: from Bankruptcy to market leader. Journal of Small Business \& Entrepreneurship, 27(6), 519-536. https://doi.org/10.1080/ 08276331.2015.1092851

Mayr, S., Mitter, C., \& Aichmayr, A. (2017). Corporate crisis and sustainable reorganization: Evidence from bankrupt Austrian SMEs. Journal of Small Business Management, 55(1), 108-127. https://doi.org/10.1111/jsbm.12248

McGrath, R. G., \& MacMillan, I. C. (2000). The entrepreneurial mindset: Strategies for continuously creating opportunity in an age of uncertainty (Vol. 284). Harvard Business Press.

Mitchell, V. (1994). The dynamics of evolving markets: the effects of business sales and age on dissolutions and divestures. Administrative Science Quarterly, 39(4): 575-602. https://doi.org/10.2307/2393772

Mulling, D., Silveira, M., Dutra, M., \& Lauren, A. (2015). Value Creation from Internationalization of Sugar Cane byproducts: a multi-stakeholder view of artisanal cachaça production. Revista Brasileira de Gestão de Negócios, 17(55), 890910. https://doi.org/10.7819/rbgn.v17i55.2134

Mutezo, A. (2013). Credit rationing and risk management for SMES: The way forward for South Africa. Corporate Ownership \& Control, 10(2), 153-163. https://doi.org/10. 22495/cocv10i2c1art1

Nigam, N., \& Boughanmi, A. (2017). Can innovative reforms and practices efficiently resolve financial distress? Journal of Cleaner Production, 140(3), 1860-1871. https: //doi.org/10.1016/j.jclepro.2016.09.190

Nilsen, J. (2002). Trade credit and the bank lending channel. Journal of Money, Credit, and Banking, 34(1), 226-253. https://doi.org/10.1353/mcb.2002.0032

Ohlson, J.A. (1980). Financial Ratios and the Probabilistic Prediction of Bankruptcy. Journal of Accounting Research, 18(1), 109-131. https://doi.org/10.2307/2490395

Organisation for Economic Co-Operation and Development (OECD) (2006). The SME Financing Gap (Volume 1): Theory and Evidence. Paris: OECD Publishing.

Organisation for Economic Co-Operation and Development (OECD) (2009). The Impact of the Global Crisis on SME and Entrepreneurship Financing and Policy Responses, Available at: http://www.oecd.org/cfe/smes/43183090.pdf

Pastena, V., \& Ruland, W. (1986). The Merger/Bankruptcy Alternative. The Accounting Review, 6(2), 288-301.

Peacock, R. W. (1985). Finding the causes of small business failure. Management Forum, 11(2), 77-89.

Peel, M. J., \& Wilson, N. (1996). Working capital and financial management practices in the small firm sector. International Small Business Journal, 14(2), 52-68. https://doi. org/10.1177/0266242696142004

Perry, C., \& Pendleton, W. (1984). Successful small business management. Sidney: Pitman Publishing.

Peterson, R.A., Kozmetsky, G., \& Ridgeway, N.M. (1983). Perceived Causes of Small Business Failures: A Research Note. American Journal of Small Business, 8(1), 15-19. https://doi. org/10.1177/104225878300800106

Pike, R., \& Pass, C. (1987). Management of working cap- ital: A neglected subject. Management Decision, 25(1), 18-24. https://doi.org/10.1108/eb001430

Poston, K.M., \& Harmon, W.K. (1994). A Test Financial Ratios as Predictors of Turnaround versus Failure among Financially Distressed Firms. Journal of Applied Business Research, 10(1), 41-57. https://doi.org/10.19030/jabr.v10i1.5962

Poutziouris, P., Chittenden, F., \& Michaelas, N. (1998). The Financial Affairs of Private Companies. Liverpool: Tilney Fund Management.

Reuer, J. J., \& Leiblein, M. J. (2000). Downside risk implications of multinationality and international joint ventures. Academy of Management Journal, 43(2), 203-214. https:// doi.org/10.5465/1556377.

Roe, M.J. (1983). Bankruptcy and debt: a new model for corporate reorganization. Columbia Law Review 83, 527. https://doi.org/10.2307/1122304

Rose-Green, E., \& Lovata, L. (2013). The relationship between firms' characteristics in the periods prior to bankruptcy filing and bankruptcy outcome. Accounting and Finance Research, 2(1), 97. https://doi.org/10.5430/afr. v2n1p97

Routledge, J., \& Gadenne, D. (2000). Financial distress, reorganization and corporate performance. Accounting \& Finance, 40(3), 233-259. https://doi.org/10.1111/1467-629X. 00046

Sharma, A., \& Kesner, I.F. (1996). Diversifying entry: some ex ante explanations for post-entry survival and growth. Academy of Management Journal, 39(3), 635-677. https: //doi.org/10.5465/256658

Shepherd, D. A. (2003). Learning from business failure: Propositions of grief recovery for the self-employed. Academy of Management Review, 28(2), 318-328. https://doi.org/10. 5465/amr.2003.9416377

Sirmon, D. G., \& Hitt, M. A. (2003). Managing resources: Linking unique resources, management, and wealth creation in family firms. Entrepreneurship theory and practice, 27(4), 339-358. https://doi.org/10.1111/1540-8520.t01-1-00013

Sirmon, D. G., Hitt, M. A., \& Ireland, R. D. (2007). Managing firm resources in dynamic environments to create value: Looking inside the black box. Academy of management review, 32(1), 273-292. https://doi.org/10.5465/amr.2007. 23466005

Sitkin, S. B. (1992). Learning through Failure: The Strategy of Small Losses. Research in Organizational Behavior, 14, 231-266.

Stiglitz, J. E., \& Weiss, A. (1981). Credit rationing in markets with imperfect information. The American economic review, 71(3), 393-410.

St-Pierre, J. (1999) La gestion financière des PME: théories et pratiques. Québec: Presses de l'Université du Québec.

Thompson, J. D. (1967). Organizations in action: Social science bases of administrative theory. New York: McGrawHill.

Thornhill, S., \& R. Amit (2003). Learning from Failure: Bankruptcy, Firm Age and the Resource-based View. Organization Science, 14(5), 497-509. https://doi.org/10.1287/ orsc.14.5.497.16761

Ucbasaran, D., Shepherd, D. A., Lockett, A., \& Lyon, S. J. (2013). Life after business failure: The process and consequences of business failure for entrepreneurs. Journal of Management, 39(1), 163-202. https://doi.org/10.1177/ 0149206312457823

Ullmann, A. A. (1985). Data in search of a theory: A critical examination of the relationships among social performance, social disclosure, and economic performance of 
US firms. Academy of Management Review, 10(3), 540-557. https://doi.org/10.5465/amr.1985.4278989

Van Hemmen, E. (2000). Reasignación de Recursos y Resolución de Contratos en el Sistema Concursal Español. Paper presented to X ACEDE National Congress. Oviedo.

Walker, E. W., \& Petty, J. W. (1978). Financial differences between large and small firms. Financial Management, 7(4), 61-68. https://doi.org/10.2307/3665087

Wang, C. A. (2012). Determinants of the choice of formal bankruptcy procedure: An international comparison of reorganization and liquidation. Emerging Markets Finance and Trade, 48(2), 4-28. https://doi.org/10.2753/ REE1540-496X480201

White, M. (1981). Economics of Bankruptcy: Liquidation and Reorganization. Working paper, New York University, August.

White, M. (1983). Bankruptcy Costs and the new Bankruptcy Code. Journal of Finance, 38 (2), 477-487. https: //doi.org/10.2307/2327983

Wilson, P., \& Gorb, P. (1983). How large and small firms can grow together. Long Range Planning, 16(2), 19-27. https: //doi.org/10.1016/0024-6301(83)90052-3

Yost, K. (2002). The choice among traditional Chapter 11 , prepackaged bankruptcy, and out-of-court restructuring. Working paper, University of Wisconsin-Madison.

Zimmerer, T.W., \& Scarborough, N.M. (1994). Essentials of Small Business Management. New York: Macmillan College Publishing Company. 
Return on total assets

Operating margin

\section{Operating} result/operating income and taxes/net total assets

The degree of advantage of the assets and therefore the efficiency of the company in Earning before interests The degree of advantage of the assets and therefore the efficiency of the compelopment of their operational functions. A higher value for this ratio indicates a greater capacity of the economic structure of the company to generate earnings and a greater probability of continuing their activity in the future.

The commercial efficiency of the company or contribution of the operating income to the result with the object of observing the weight of the expenses on the earnings. The greater the ratio is, the greater the contribution of income will be to the operating result and thereby the efficiency of the company in its commercial management.

Capacity of the assets to generate sales. A greater value of this ratio, for identical commercial margins, supposes greater earnings for an inferior investment and

Assets turnover Net sales/net total assets therefore an increase in income. This ratio is indicative of the relative efficiency of the company in asset management; accordingly, the company is more efficient and will have a greater probability of survival.

Return on equity Net income/equity

Efficiency of the company in the application of the equity. It is the average earnings obtained by the company, so the greater this ratio is, the greater the possibilities of company continuity will be.

Another way of measuring economic profitability, but in this case, the amount of

Cash return on Cash flow/net total cash flow from operations is considered as an indicator of profitability. For the assets assets return on total assets, a greater value of this ratio indicates a greater probability of survival.

Return on tangible Earnings before Contribution of the tangible fixed assets to the generation of resources. As in the previous case, this variable constitutes another way of measuring economic

fixed assets taxes/non-current assets profitability. However, it is restricted to the tangible fixed assets, which allows a degree of economic efficiency.

Importance of the financial expenses (interests) on the total of the debt. This

Interest expenses to total debt
Financial expenses/total liabilities variable is an indicator of financial management; the smaller the financial expenses originated by each unit of debt is, the more efficient the company will be in the management of the financing and it will have a greater probability to access new sources of financing with which to confront a situation of business failure.

\section{RATIOS OF ECONOMIC STRUCTURE}

Non-current assets Net non-current

to total assets

Current assets to total assets

Tangible noncurrent assets to total assets

Intangible noncurrent assets to total assets

Non-current investments to total assets assets/net total assets

Net current assets/net total assets

Net tangible non-current Weight of tangible non-current assets (property, plant and equipment) within total assets/net total assets assets.

Net intangible non-

current assets/net total Weight of intangible non-current assets within total assets. assets

Non-current

investments/net total Weight of non-current investments within total assets. assets

Inventory to total Inventory/net total assets assets

Weight of inventory within total assets.

Receivables to total Current receivables/net assets total assets

Weight of trade and other current receivables within total assets.

Cash and cash

Cash to total assets equivalents/net total Weight of cash and cash equivalents within total assets. assets

RATIOS OF FINANCIAL STRUCTURE

\section{Debt to total} internal and external financial funds

Retained benefits to equity

Long-term debts to Non-current total debt liabilities/tot

Total liabilities/ (capital and reserves + total liabilities) external financial funds. total equity. long-term creditors within the financial structure.
Weight of non-current assets within total assets.

Weight of current assets within total assets.

Weight of the short-term and long-term debt with respect to the total internal and

The degree of capitalization of the company, and therefore, the weight of the Retained benefits/equity earnings retained (without considering the negative results of previous years) over

Weight of the long-term debt in the total debt. This ratio reflects the importance of

The importance of short-term liabilities in total liabilities, which allows the situation

Short-term debts to total debt

Current liabilities/total liabilities of financial stability or instability derived from the composition of the financial structure to be detected. Therefore, it can be indicative of the margin available to the company to transform short-term debt into long-term debt. 


$\begin{array}{ll} & \text { (Equity + total } \\ \text { Capital to debt } & \text { liabilities) /total } \\ \text { liabilities }\end{array}$

RATIOS OF SOLVENCY AND LIQUIDITY

Cash flow to

current debt

Cash flow/(financial expenses + short-term debts)

Cash flow to total debt

$\begin{array}{ll}\begin{array}{l}\text { Cash flow to } \\ \text { current liabilities }\end{array} & \begin{array}{l}\text { Cash flow/short-term } \\ \text { liabilities } \\ \text { Current assets/current } \\ \text { liabilities } \\ \text { (Current assets - }\end{array} \\ \text { Acid test ratio } & \begin{array}{l}\text { inventory)/current } \\ \text { liabilities } \\ \text { Cash and cash } \\ \text { equivalents/current } \\ \text { liabilities }\end{array} \\ \text { Cash ratio } & \begin{array}{l}\text { Total liabilities/total } \\ \text { assets }\end{array}\end{array}$

Equity to non- Equity/non-current current assets assets

Retained benefits to total assets

Retained benefits/total assets
Permanent capital measures the relation between the level of permanent liabilities and total liabilities as an indicator of the structural composition of the liabilities. A higher ratio will be indicative of greater room to manoeuvre in unfavourable situations and, therefore, increased probabilities of survival.

\section{RATIOS OF STRUCTURE OF RESULTS}

Personnel expenses Personnel

to operating expenses/operating Weight of personnel expenses within operating income.

income income

Capacity to face financial expenses and liabilities in the short term with the generated resources.

Capacity of return on liabilities with the generated resources. The greater the ratio 列 the case of a crisis situation.

Capacity of return of liabilities in the short term.

Capacity of the company to generate enough liquid financial resources to return liabilities in the short term.

Calculated as current assets less the inventory. This ratio sheds light on the capacity of the company to face a critical situation in the very short term.

Immediate liquidity or capacity of the company to return the short-term liabilities from the productive or commercial cycle.

Guarantee or distance to bankruptcy: Capacity of the assets to confront the totality of the debts. Therefore, it constitutes the guarantee of the creditors in a hypothetical case of liquidation of the company.

The part of the fixed assets financed by own resources and, therefore, the correlation between investment and financing. It is a measurement of the part of the assets that are covered by own resources and long-term liabilities. It represents the margin of the company between the availability and the exigibility of resources.

Indicator of the trajectory of the company with regard to the generation and retention of resources. In addition, it shows the possibility of having additional resources to reduce the problems of liquidity of companies with financial problems; therefore, the greater the retention of resources are with respect to the assets of the company, the greater their probabilities of reconstruction will be.

$\begin{array}{ll}\begin{array}{l}\text { Depreciation to } \\ \text { operating income }\end{array} & \begin{array}{l}\text { Annual depreciation of } \\ \text { assets/operating income }\end{array}\end{array}$ Weight of the annual depreciation of assets within operating income.

Financial expenses Financial

to operating expenses/operating Weight of financial expenses within operating income.

income income

Operating Operating

expenses to expenses/operating Weight of the operating expenses within operating income.

operating income income

\section{RATIOS OF PARTICIPATION ON ADDED VALUE AND PRODUCTIVITY}

Added value to Added value/operating Measurement of the global productivity of the company. The greater the ratio is, the operating income income greater the probabilities of survival of the company will be.

Depreciation to Annual depreciation of Asset efficiency, as well as the part of added value generated by the company that is added value assets/added value

Personnel expenses Personnel

to added value expenses/added value

Financial expenses Financial

to added value expenses/added value destined to cover the depreciations of assets.

Weight of the expenses of personnel over the added value generated by the company.

Participation of lenders in production and, consequently, part of the added value that is destined to the remuneration of loans.

Taxes to added Taxes/added value Weight of the taxes over the productive process.

\section{OTHER VARIABLES}

\begin{tabular}{lcl}
\hline Firm size & $\begin{array}{c}\text { Natural logarithm of } \\
\text { total assets } \\
\text { Industry }=1\end{array}$ & Variable is adjusted for changes in the consumer price index. \\
Activity sector & Construction $=2$ \\
& Services $=3$ & \\
Firm age & $\begin{array}{c}\text { Year } 2010-\text { year of } \\
\text { foundation }\end{array}$ & Number of years since the firm was founded (until the year 2010). \\
\hline
\end{tabular}

